\title{
Mercury toxicity risk and corticosterone levels across the breeding range of the Yellow-breasted Chat
}

\author{
Kristen Mancuso $\mathbb{D}^{1} \cdot$ Karen E. Hodges ${ }^{1} \cdot$ Manuel Grosselet $^{2} \cdot$ John E. Elliott $^{3} \cdot$ John D. Alexander ${ }^{4}$ \\ Michelle Zanuttig $^{3}$. Christine A. Bishop ${ }^{3}$
}

Accepted: 23 November 2021 / Published online: 1 January 2022

(C) The Author(s) 2021

\begin{abstract}
Mercury $(\mathrm{Hg})$ is an environmental contaminant that can negatively impact human and wildlife health. For songbirds, $\mathrm{Hg}$ risk may be elevated near riparian habitats due to the transfer of methylmercury $(\mathrm{MeHg})$ from aquatic to terrestrial food webs. We measured $\mathrm{Hg}$ levels in tail feathers sampled across the breeding range of the Yellow-breasted Chat (Icteria virens), a riparian songbird species of conservation concern. We assessed the risk of $\mathrm{Hg}$ toxicity based on published benchmarks. Simultaneously, we measured corticosterone, a hormone implicated in the stress response system, released via the hypothalamus-pituitary-adrenal axis. To better understand range-wide trends in $\mathrm{Hg}$ and corticosterone, we examined whether age, sex, subspecies, or range position were important predictors. Lastly, we examined whether $\mathrm{Hg}$ and corticosterone were correlated. $\mathrm{Hg}$ levels in chats were relatively low: $0.30 \pm 0.02 \mu \mathrm{g} / \mathrm{g}$ dry weight. 148 out of $150(98.6 \%)$ had $\mathrm{Hg}$ levels considered background, and $2(1.6 \%)$ had levels considered low toxicity risk. Hg levels were similar between sexes and subspecies. Younger chats ( $<1$ year) had higher $\mathrm{Hg}$ levels than older chats ( $>1$ year). Hg levels were lowest in the northern and central portion of the eastern subspecies' range. Corticosterone concentrations in feathers averaged $3.68 \pm 0.23 \mathrm{pg} / \mathrm{mm}$. Corticosterone levels were similar between ages and sexes. Western chats had higher levels of corticosterone than eastern chats. $\mathrm{Hg}$ and corticosterone were not correlated, suggesting these low $\mathrm{Hg}$ burdens did not affect the activity of the hypothalamus-pituitary-adrenal axis. Altogether, the chat has low $\mathrm{Hg}$ toxicity risk across its breeding range, despite living in riparian habitats.
\end{abstract}

Keywords Yellow-breasted Chat $\cdot$ Mercury $\cdot$ Corticosterone $\cdot$ Songbird

\section{Introduction}

Mercury $(\mathrm{Hg})$ is an environmental contaminant of concern to wildlife and humans because it can negatively affect reproduction, neurology, immunology, and behaviour

Supplementary information The online version contains supplementary material available at https://doi.org/10.1007/s10646021-02510-6.

Kristen Mancuso

kmancuso88@gmail.com

1 Department of Biology, University of British Columbia Okanagan, Kelowna, BC, Canada

2 Tierra de Aves, Veracruz, Mexico

3 Science and Technology Branch, Environment and Climate Change Canada, Delta, BC, Canada

4 Klamath Bird Observatory, Ashland, OR, USA
(Wolfe et al. 1998; Scheuhammer et al. 2007; Seewagen 2010; Fuchsman et al. 2017). Hg from anthropogenic sources (e.g. chlor-alkali plants, coal burning, waste incineration, gold-mining) and naturally occurring sources (e.g. volcanic activity, forest fires) can travel vast distances in the atmosphere before settling in soil and waterways (Driscoll et al. 2007, 2013; AMAP/UN Environment 2019). There, under anoxic conditions, inorganic $\mathrm{Hg}$ is transformed by mostly methylating bacteria into its most biohazardous form, methylmercury $(\mathrm{MeHg})$, and readily moves through food webs (Driscoll et al. 2007, 2013; Cristol et al. 2008).

In birds, ingested $\mathrm{Hg}$ enters the bloodstream and becomes stored in tissues and organs, primarily the liver, kidneys, brain, and muscles (Braune and Gaskin 1987; Whitney and Cristol 2017a). During the period of feather growth, $\mathrm{Hg}$ in blood becomes encapsulated into the feathers and remains inert thereafter (Furness et al. 1986). Hg content in the blood includes a combination of recent dietary exposure and body burden accumulated since the last moult 
cycle (Honda et al. 1986; Braune and Gaskin 1987; Thompson et al. 1991; Monteiro and Furness 2001; Bottini et al. 2021). Feathers are the main pathway for birds to rid their body of $\mathrm{Hg} ; 70-93 \%$ of the body burden gets incorporated into feathers (Honda et al. 1986; Braune and Gaskin 1987; Agusa et al. 2005; Whitney and Cristol 2017a; Albert et al. 2019). Females also depurate Hg through egg-laying (Scheuhammer 1987; Rimmer et al. 2005; Robinson et al. 2012). Therefore, mercury encapsulated in feathers represents the accumuation of $\mathrm{Hg}$ between moulting cycles and can provide insight into $\mathrm{Hg}$ exposure across the full-annual cycle (Albert et al. 2019).

Recent evidence suggests that songbirds, especially those that use riparian, aquatic, and wetland habitats, may be at risk of $\mathrm{Hg}$ exposure through the consumption of carnivorous and aquatic invertebrates (Rimmer et al. 2005; Brasso and Cristol 2008; Edmonds et al. 2010; Evers et al. 2012; Jackson et al. 2015; Ackerman et al. 2016; Pacyna et al. 2017 but see Brasso et al. 2020). Because Hg biomagnifies, songbirds that consume arthropods at higher trophic levels, including spiders, can accumulate elevated levels of $\mathrm{Hg}$ (Rimmer et al. 2005; Cristol et al. 2008; Keller et al. 2014; Li et al. 2021).

The identification of songbird populations at risk of $\mathrm{Hg}$ toxicity is important because multiple sublethal effects may affect the persistence of a population. $\mathrm{Hg}$ reduces body condition and negatively affects the immune function in birds, therefore, individuals may be less equipped to fend off diseases and parasites (Whitney and Cristol 2017b; Ackerman et al. 2019). Hg exposure can negatively affect reproduction through altered nest-building (Chin et al. 2017), reduced courtship behaviour (Heddle et al. 2020), smaller egg size, smaller clutches (Brasso and Cristol 2008, but see Heddle et al. 2020), and lowered nest success through hatchling mortality (Scheuhammer 1987; Custer et al. 2007; Jackson et al. 2011; Heddle et al. 2020). Early developmental exposure to $\mathrm{Hg}$ can affect survival, reproduction, behaviour, and neuroanatomical development ( $\mathrm{Yu}$ et al. 2017; Paris et al. 2018; Heddle et al. 2020). Moreover, $\mathrm{Hg}$ may negatively affect migration and overwinter survival, further contributing to the decline of migratory songbirds (Ma et al. 2018; Seewagen 2020).

Of additional concern, $\mathrm{Hg}$ can act as a stressor disrupting the normal functioning of the stress response system (Wada et al. 2009; Franceschini et al. 2009; Herring et al. 2012; Moore et al. 2014 but see Tartu et al. 2015a, b; Maddux et al. 2015). The stress response involves the release of glucocorticoids into the bloodstream via adrenal glands through the hypothalamus-pituitary axis (Siegel 1980; Wingfield 2013). In birds, the main glucocorticoid is corticosterone (Siegel 1980; Romero 2004). A wide range of negative effects, including weakened immune systems, hypertension, neuronal cell death, memory loss, and negative fitness consequences are attributed to chronic stress, which can present itself as increased or decreased levels of corticosterone (Busch and Hayward 2009; Kleist et al. 2018).

Like $\mathrm{Hg}$, corticosterone circulating in the blood is deposited into feathers during the period of feather growth and remains inert thereafter (Jenni-Eiermann et al. 2015). In contrast to $\mathrm{Hg}$, corticosterone is a short-lived hormone and feather concentrations represent integrated levels in the blood during the period of growth over the span of several weeks (Bortolotti et al. 2008; Lattin et al. 2011). Measuring $\mathrm{Hg}$ and corticosterone in feathers is a non-invasive technique that can be used to address concerns about conservation physiology (Jenni-Eiermann et al. 2015). This is especially advantageous for species or populations that may be at risk and where more invasive methods might not be advised (Bortolotti et al. 2008).

Here, we examine trends in $\mathrm{Hg}$ and corticosterone across the breeding range of the Yellow-breasted Chat (Icteria virens, hereafter chat). The geographic scope of our study combining $\mathrm{Hg}$ and corticosterone in chats is unprecedented. The chat is a neotropical migrant songbird whose habitat consists of dense, shrubby thickets in or near riparian habitats - a habitat zone generally believed to be a hotspot for Hg (Jackson et al. 2015; Eckerle and Thompson 2020). Additionally, given that $\mathrm{Hg}$ can transcend aquaticterrestrial interfaces via invertebrate vectors, the Yellowbreasted Chat may be exposed to $\mathrm{Hg}$ through the consumption of invertebrates in these riparian habitats. The diet of the Yellow-breasted Chat consists of terrestrial invertebrates (ants, wasps, spiders, beetles, leafhoppers) and also plant matter (Yard et al. 2004; McKibbin and Bishop 2008; Eckerle and Thompson 2020). Probing deeper into the conservation physiology for this species may prove valuable for conservation efforts, as several populations are of conservation concern in Canada and the United States (British Columbia, Ontario, Environment and Climate Change Canada 2016, 2019; California, Shuford and Gardali 2008; Connecticut, State of Connecticut 2015; New York, New York State 2019). In our study, we measured $\mathrm{Hg}$ and corticosterone concentrations in feathers across the breeding range of the chat. Secondly, we converted feather $\mathrm{Hg}$ levels to equivalent blood $\mathrm{Hg}$ concentrations to assess $\mathrm{Hg}$ toxicity risk based on published benchmarks. Thirdly, we explored whether range-wide patterns of $\mathrm{Hg}$ and corticosterone could be explained by age, sex, range position, or subspecies. Lastly, we examined the relationship between $\mathrm{Hg}$ and corticosterone to see if there was evidence of $\mathrm{Hg}$ accumlated since the last moult cycle affecting the function of the hypothalamus-pituitaryadrenal axis. 
Table 1 Yellow-breasted Chat (Icteria virens) study site locations where feather samples were collected for corticosterone (Cort), mercury $(\mathrm{Hg})$, and hydrogen stable isotope analyses $\left(\delta^{2} \mathrm{H}_{\mathrm{f}}\right)$

\begin{tabular}{|c|c|c|c|c|c|c|c|}
\hline \multirow[t]{2}{*}{ Site } & \multirow[t]{2}{*}{ Latitude } & \multirow[t]{2}{*}{ Longitude } & \multirow[t]{2}{*}{$\begin{array}{l}\text { Elevation } \\
(\mathrm{m})\end{array}$} & \multirow[t]{2}{*}{ Years } & \multicolumn{3}{|c|}{$\begin{array}{l}\mathrm{N} \text { (individuals } \\
\text { sampled) }\end{array}$} \\
\hline & & & & & Cort & $\mathrm{Hg}$ & $\delta^{2} \mathrm{H}_{\mathrm{f}}$ \\
\hline \multicolumn{8}{|l|}{ Breeding } \\
\hline $\begin{array}{l}\text { South Okanagan Valley, British } \\
\text { Columbia, CA }\end{array}$ & 49.094 & -119.537 & 300 & 2017,2018 & 20 & 20 & $15^{\mathrm{a}}$ \\
\hline Trinity River, California, US & 40.695 & -122.854 & 500 & 2017,2018 & 16 & 20 & $15^{\mathrm{a}}$ \\
\hline WIIM, Oregon I, US & 42.490 & -123.480 & 251 & 2018 & 8 & 13 & $7^{\mathrm{a}}$ \\
\hline TOPS, Oregon II, US & 42.019 & -122.140 & 905 & 2018 & 3 & 5 & $2^{\mathrm{a}}$ \\
\hline \multicolumn{8}{|l|}{ Migration } \\
\hline $\begin{array}{l}\text { Santa Alejandrina Bird Observatory, } \\
\text { Veracruz, MX }\end{array}$ & 18.002 & -94.588 & 4 & 2014,2015 & 100 & 36 & 36 \\
\hline $\begin{array}{l}\text { La Encrucijada Biosphere Reserve, } \\
\text { Chiapas, MX }\end{array}$ & 15.552 & -93.206 & 3 & 2018 & 30 & 36 & 36 \\
\hline \multicolumn{8}{|l|}{ Overwinter } \\
\hline San Pancho Bird Observatory, Nayarit, MX & 20.905 & -105.398 & 33 & 2018,2019 & 19 & 20 & 20 \\
\hline Total & & & & & 196 & 150 & 92 \\
\hline
\end{tabular}

The breeding location of chats sampled during migration and overwintering was inferred using stable hydrogen isotopes

${ }^{\text {a }}$ These samples were collected only to calibrate the precipitation isoscape and are not included in the total

\section{Methods}

\section{Study areas}

We sampled chats in seven study areas. Four areas were known breeding locations in British Columbia, Canada, and California and Oregon, USA (Table 1, Fig. 1). The remaining three study areas were in Mexico in Nayarit, Chiapas, and Veracruz, where chats were sampled during migration and the non-breeding period. Breeding location was inferred from Mexico sites using hydrogen stable isotope analyses and genetics (Mancuso 2020).

All breeding sites were in riparian areas. The British Columbia study area was along the channelized South Okanagan River (McKibbin and Bishop 2010). Three Klamath Bird Monitoring Network (Alexander et al. 2004; Alexander 2011) areas included one along the Trinity River in California (Rockwell and Stephens 2018) and two Oregon study areas, WIIM along the Rogue River and TOPS along the Klamath River (Rockwell et al. 2017). The Nayarit study area consisted of openings and edges of semi-deciduous tropical forests. The Chiapas study site was located within the La Encrujijada Biosphere Reserve near the Pacific Ocean within a large open wetland surrounded by small patches of trees and tall grasses. The Veracruz, Mexico study site was adjacent to a wetland area and surrounded by shrubs and short trees (Gahbauer et al. 2016).

\section{Bird handling and feather collection}

In British Columbia and California, chats were captured and sampled during the breeding season between May and August of 2017 and 2018. In Oregon, chats were captured

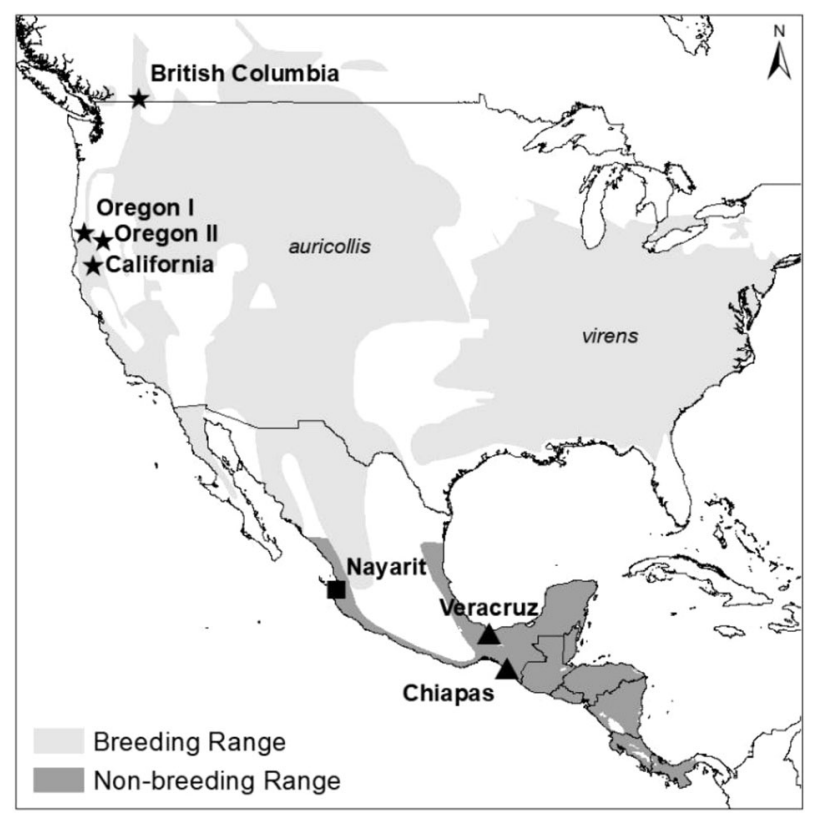

Fig. 1 Study areas for Yellow-breasted Chats (Icteria virens). The breeding ranges of the eastern (I.v. virens) and western (I.v. auricollis) subspecies are shown. Star symbols represent birds sampled from study areas in the breeding season, the square represents birds sampled from a study area in the overwintering season, and triangles represent birds sampled from study areas during migration. Map made in ArcMap 10.7.1 (ESRI 2019) using a WGS 1984 Web Mercator projection and coordinate system

and sampled in 2018 between May and July but two birds were sampled in September. In Veracruz, chats were sampled in March, May, August to November 2014, and March 2015, and we assumed that these were migrating chats. In Chiapas, chats were sampled in September and October of 2018; we assumed these were migrating chats. In Nayarit, 
chats were sampled in January and February 2018 and 2019, and we assume these were overwintering chats.

Chats were caught in mist nets often with the aid of callplayback and taxidermied or wooden painted decoys. Birds were removed from nets, sexed according to (Pyle 1997), placed into age categories defined by Wolfe et al. (2010), and banded. Birds that could not clearly be distinguished as male or female were classified as unknown sex. The right outer rectrix feather was collected for corticosterone analyses. The left outer rectrix feather was collected for $\mathrm{Hg}$ analyses. One secondary feather (S1-S6) was collected for hydrogen stable isotope analysis. Birds were processed as quickly as possible (a few minutes) and released at the capture site.

\section{Moult and its interpretation of $\mathrm{Hg}$ and corticosterone}

Chats have a complex-basic moult strategy. They undergo an incomplete preformative moult during their first annual cycle and a complete definitive prebasic moult during subsequent annual cycles (Pyle 1997; Wolfe et al. 2010). Chats likely complete preformative and definitive prebasic moults on their natal/breeding grounds prior to fall migration (Pyle 1997; pers. obs). The preformative moult in chats includes the outer primaries, inner secondaries, tertials, greater coverts, and up to two inner tail feathers (Pyle 1997). In our western study areas, some chats replace these inner tail feathers during their preformative moult, however, many do not (pers. comm from Matthias Bieber; Pyle 1997). In contrast, Grosselet et al. (2014) found that most eastern chats captured in Veracruz, Mexico had replaced all of their tail feathers during their preformative moults. Therefore, in our study the first cycle outer tail feathers collected for western chats were likely grown in the nest, whereas the first cycle outer tail feathers collected for eastern chats were likely grown on the natal grounds during their preformative moult.

Knowing when and where a chat feather was grown has important implications for our interpretation of $\mathrm{Hg}$ and corticosterone. Tail feathers from chats in their first moult cycle encapsulate $\mathrm{Hg}$ exposure since hatching (i.e. $\sim 10$ days for western chats, and up to several months for eastern chats). Feathers from birds in their definitive moult cycle encapsulate $\mathrm{Hg}$ exposure over $\sim 1$ year since their last moult, including breeding, migration, and the non-breeding season (Evers et al. 2005; Warner et al. 2012; Jackson et al. 2015).

Corticosterone does not accumulate in the body and, therefore, represents the hormonal profile on the breeding grounds during the period of feather growth only ( 1-2 weeks), either during the nestling period (e.g. first moult cycle of western chats) or before fall migration (e.g. first moult cycle of eastern chats and all chats in their definitive moult cycle (Bortolotti et al. 2008).

\section{Breeding assignment of overwintering birds}

To determine the breeding origin of chats sampled in Mexico, we measured hydrogen stable isotope ratios in feathers (Mancuso 2020). Hydrogen stable isotope values in precipitation vary latitudinally across the landscape and this chemical signature becomes incorporated into animal tissues (Hobson and Wassenaar 2008). Therefore, by examining the hydrogen stable isotope contents of animal tissue (feathers in this case), one can infer where the tissue was grown (Hobson and Wassenaar 1997).

In brief, feathers were washed in a solvent to remove any impurities, air dried, and cut into small pieces. Feathers were sent to the Laboratory of Stable Isotope Science at the University of Western Ontario, London, Ontario, Canada for analyses. Stable hydrogen isotope composition was determined using an elemental analyzer where samples undergo pyrolysis by heating to $1120^{\circ} \mathrm{C}$. Samples were calibrated using the most recent values for Caribou Hoof Standard and Kudu Horn Standard (Soto et al. 2017). Samples of standard powered keratin (Spectrum-1) were measured intermittently to assess and correct for drift. Random feather samples were run in duplicate for further quality assurance/quality control and were averaged during reporting. The standard notation of stable hydrogen isotopes $\left(\delta^{2} \mathrm{H}\right)$ is parts per thousand $(\% o)$ relative to Vienna Standard Mean Ocean Water. A subscript $F$ is included when referring to feathers, or $\mathrm{P}$ when referring to precipitation hydrogen isotope ratio values.

A precipitation isoscape for North America was created using publicly available $\delta^{2} \mathrm{H}_{\mathrm{p}}$ values in rainwater from the Global Network of Isotopes in Precipitation (IAEA/WMO 2019). The package IsoriX (v0.8.2; Courtiol et al. 2019) in $\mathrm{R}$ (v3.5.1.; R Core Team 2018) was used to create the precipitation isoscape and then calibrated using Yellowbreasted Chat feather samples of known breeding origin (Mancuso 2020).

To estimate the breeding origin of chats, $\delta^{2} \mathrm{H}_{\mathrm{f}}$ values were placed into $10 \%$ bins and a group location was estimated using the isofind function of IsoriX. Group location estimates were exported as a raster file to create maps in ArcMap 10.7.1 (ESRI 2019). Location estimates were constrained to breeding ranges based on subspecies identification previously determined using genetics (Mancuso 2020). The western subspecies (I.v. auricollis) breeds in the western United States, southwestern Canada, and northwestern Mexico (Fig. 1, IUCN 2016; Eckerle and Thompson 2020). The eastern subspecies (I.v. virens) breeds in the eastern United States and the very southern tip of Ontario, Canada (Fig. 1, IUCN 2016; Eckerle and Thompson 2020). 


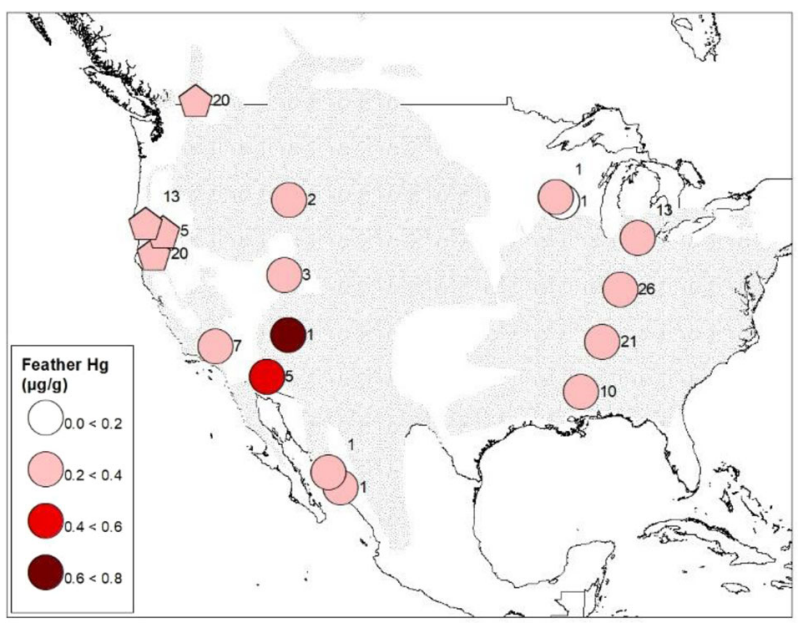

Fig. 2 Average mercury concentrations in Yellow-breasted Chats (Icteria virens) in their breeding range. Pentagons are sites where chats were sampled during the breeding season. Circles are breeding sites inferred from stable hydrogen isotope analyses; a single point was used to map these inferred groups that span larger areas based on assignment probabilities. Sample sizes are indicated beside each point. The breeding range of the Yellow-breasted Chat is shown in stippled grey in the background (IUCN 2016). Map made in ArcMap 10.7.1 (ESRI 2019) using a WGS 1984 Web Mercator projection and coordinate system. Note that while higher mercury concentrations are shown as darker shades of red, all levels are still considered low risk of mercury toxicity

We showed genetically that chats in Chiapas and Veracruz were of the eastern subspecies while chats from Nayarit were of the western subspecies (Mancuso 2020). In order to visualize the geographic assignment locations from the $10 \%$ o hydrogen isotopic bins, a single representative point was used (Appendix I, Fig. 2).

\section{Hg analyses}

We measured total $\mathrm{Hg}$ concentration in 150 chat feathers (Table 1). Samples were analyzed by the National Wildlife Research Centre in Ottawa, Ontario, Canada. Feathers were washed with acetone, then a solution of $0.25 \%$ Triton X100 , then twice in ultrapure water before being air-dried for $\geq 48 \mathrm{~h}$. Cleaned samples were freeze-dried and ground into a homogenous powder. Samples were placed into the autosampler on nickel boats, then decomposed under a continuous flow of ultra-pure oxygen within a quartz catalytic tube. The products of combustion were oxidized and carried to a gold amalgamator that targets $\mathrm{Hg}$. $\mathrm{Hg}$ is released by heating and carried through absorbance cells within an atomic absorption spectrophotometer. The absorbance was measured at $253.7 \mathrm{~nm}$. Sample values for $\mathrm{Hg}$ are reported in $\mu \mathrm{g} / \mathrm{g}$ dry weight (dw). As most of the $\mathrm{Hg}$ present in feathers is $\mathrm{MeHg}$, total $\mathrm{Hg}$ content represents $\mathrm{MeHg}$ concentration (Kim et al. 1996; Bond and Diamond 2009; Souza et al. 2020), which is the organic and biohazardous form of $\mathrm{Hg}$.
Accuracy was evaluated at the start of each day with a minimum of four standard reference materials. To maintain accuracy, standard reference materials were analyzed at regular intervals and at the end of each day. The standard reference materials included mussel tissue, lobster hepatopancreas, tuna fish, fish flesh and, human hair (spiked). The average recovery $( \pm \mathrm{SE})$ of $\mathrm{Hg}$ from standard reference materials was $99.3 \pm 0.51 \%$ across 8 days and 55 tests. The method detection limit was determined using 10 consecutive analyses of a standard reference material containing a low concentration of $\mathrm{Hg}$. The method detection limit as determined on August 12, 2019, based on five mg of SRM Oyster Tissue $1566 \mathrm{~b}$ was $0.024 \mathrm{ng}$. Reported method detection limits were adjusted for each sample based on mass and varied between $0.003-0.018 \mu \mathrm{g} / \mathrm{g} \mathrm{dw}$.

\section{Corticosterone extraction and assay}

We followed standard feather corticosterone extraction methods for 197 chat feathers (Bortolotti et al. 2008; Fairhurst et al. 2015; Harris et al. 2016). Each feather was washed with $\sim 1 \%$ dilute soap to remove any surface contaminants and then rinsed with ultrapure water. The feathers were air-dried overnight. The calamus was discarded and the length of the feather was measured to the nearest millimetre. The feather was cut into small pieces using fine scissors within a glass test tube and $10 \mathrm{ml}$ of $99.9 \%$ HPLC grade methanol was added. Test tubes were covered and sonicated in a water bath at room temperature for 30 minutes and then placed in a heated shaking water bath at $50{ }^{\circ} \mathrm{C}$ overnight. The feather pieces were separated from the methanol solution via vacuum filtration into a new glass test tube. A glass funnel plugged with marine PolyWool ${ }^{\mathrm{TM}}$ as a filter was fit snug to the filtration funnel using a rubber sleeve. The test tube, feather remnants, and filter were washed twice with $2.5 \mathrm{ml}$ of methanol to capture any remaining corticosterone. The methanol solution was evaporated in a fume hood under air and the extract residues were reconstituted with $300 \mu$ of assay buffer and vortexed 3 times at room temperature. The samples were placed in $1.5 \mathrm{ml}$ centrifuge tubes and centrifuged for $\sim 5$ minutes to pelletize any remaining debris or larger molecules. A volume of $100 \mu \mathrm{l}$ of the supernatant was pipetted into an Enzyme-Linked Immunosorbent Assay plate for each sample.

Corticosterone was assayed using Enzo Life Sciences Enzyme-Linked Immunosorbent Assay kit no. ADI-900097. This is a competitive binding immunoassay kit specific to the hormone corticosterone that uses a polyclonal sheep corticosterone antibody and a 96 well plate coated with donkey anti-sheep immunoglobulin G. The reported crossreactivity of these kits include $28.6 \%$ deoxycorticosterone, $1.7 \%$ progesterone, $\quad 0.13 \%$ testosterone, $0.28 \%$ 
tetrahydrocorticosterone, $0.18 \%$ aldosterone, $0.046 \%$ cortisol, $<0.03 \%$ pregnenolone, $<0.03 \% \quad \beta$-estradiol, $<0.03 \%$ cortisone, and $<0.03 \%$ 11-dehydrocorticosterone acetate (Enzo Life Sciences Inc. 2018). The reported sensitivity of the kit is $26.99 \mathrm{pg} / \mathrm{mL}$ based on two standard deviations from the blank reading using 16 replicates (Enzo Life Sciences Inc. 2018). We followed the kit instructions to determine corticosterone concentrations, culminating in reading the optical density using a microplate reader set to $405 \mathrm{~nm}$ (Enzo Life Sciences Inc. 2018). Samples were run in duplicate and averaged during reporting. Three samples of approximately $50 \%$ binding with a concentration of $600 \mathrm{pg} / \mathrm{mL}$ were added randomly to each plate to assess inter-assay variability. The inter-assay coefficient of variation was calculated as the standard deviation of the plate means divided by the mean of the means for the 8 plates. The intra-assay coefficient of variation was calculated as the overall average of the standard deviation divided by the mean for each duplicate sample for all samples for 8 plates.

To determine the corticosterone concentration of samples in the plate, the average optical density for the blank cells was subtracted from the optical density for all samples. A 4-parameter logistic model was used to create a standard curve with known corticosterone concentrations of 20,000, 4000, 800, 132, and $32 \mathrm{pg} / \mathrm{mL}$. The drc package (v. 3.2.1; Ritz et al. 2015) in programme $\mathrm{R}$ was used to create the standard curve, and the unknowns were interpolated along the standard curve using the ED function (Online Resource 1). The concentration of corticosterone within each feather was standardized to feather length and reported in values of $\mathrm{pg} / \mathrm{mm}$.

\section{Hg risk}

To examine the risk of $\mathrm{Hg}$ toxicity to chats, we compared our $\mathrm{Hg}$ values to known blood toxicity benchmarks provided by Ackerman et al. (2016) based on multiple bird species: $<0.2 \mu \mathrm{g} / \mathrm{g}$ wet weight (ww) background levels; $0.2-1.0 \mu \mathrm{g} / \mathrm{g}$ ww low risk; $1.0-3.0 \mu \mathrm{g} / \mathrm{g}$ ww moderate risk; $3.0-4.0 \mu \mathrm{g} / \mathrm{g}$ higher risk; $>4.0 \mu \mathrm{g} / \mathrm{g}$ ww severe risk. However, as Ackerman et al. (2016) rankings are based on blood $\mathrm{Hg}$ levels, we transformed our dw feather $\mathrm{Hg}$ concentrations to equivalent ww blood $\mathrm{Hg}$ concentrations.

We used two separate transfer equations from different studies to provide a more comprehensive analysis of our data. Therefore, we had two sets of blood ww $\mathrm{Hg}$ equivalents in which to assess against published $\mathrm{Hg}$ toxicity benchmarks. The first transfer equation was from EaglesSmith et al. (2008), who reviewed Hg levels across many tissue types for 4 waterbird species in San Francisco Bay, California. This equation was appealing because it was based on a large number of individuals and several species, however, the species were not landbirds. We used the transfer function reported for breast feathers because this equation was used to adjust between feathers and blood in Ackerman et al. (2016). The equation was: $\ln ($ blood $\mathrm{Hg})=$ $\ln ($ feather $\mathrm{Hg}) * 0.673-1.673$.

The second transfer function was from Jackson et al. (2011) for Carolina Wrens (Thyrothorus ludovicianus). This equation was appealing because the study was on an insectivorous landbird and outer tail feathers were used, however, it was based on a single species and in a contaminated site (Jackson et al. 2011). The re-arranged equation for blood was: blood $\mathrm{Hg}=$ (tail feather $\mathrm{Hg}$ $0.64) / 3.38$. Using the results from these two transfer functions separately, we calculated the percent of total samples that fell within each risk category.

\section{Statistical analysis}

To determine which factors influence $\mathrm{Hg}$ and corticosterone levels in chats, we used an information-theoretic approach comparing the fit of multiple models using Akaike's Information Criterion adjusted for small sample sizes $\left(\mathrm{AIC}_{\mathrm{c}}\right.$, Burnham and Anderson 2002). All values are reported as mean \pm standard error unless otherwise noted. Both $\mathrm{Hg}$ and corticosterone were transformed before analyses to improve normality and model fit as both variables were highly positively skewed. $\mathrm{Hg}$ was $\log _{\mathrm{e}}$ transformed. Corticosterone was transformed to the power of -0.7 based on a Tukey's Ladder of Powers transformation to produce a more normal distribution. Transformed variables were assessed with a Shapiro-Wilk's test to verify normality.

For Hg samples $(n=150)$, we tested 12 models containing different combinations of the parameters: age, sex, subspecies, and range location (Table 2). Age included two categories: first cycle and definitive cycle. Two chats in unknown plumage were lumped into the definite cycle age group. Age relates to the accumulation of $\mathrm{Hg}$ since the previous moult. First cycle western chats presumably represent natal $\mathrm{Hg}$ exposure as a nestling ( 1-2 weeks). First cycle eastern chats presumably represent $\mathrm{Hg}$ exposure on the natal grounds after leaving the nest ( weeks to months). Definitive cycle chats represent accumulation over the full annual cycle, including breeding, migration, and overwintering ( $\sim 1$ year).

Sex included male, female, and unknown and was included to assess potential differences in diet and the effects of $\mathrm{Hg}$ depuration through egg-laying (Scheuhammer 1987; Robinson et al. 2012; Tartu et al. 2015a).

Subspecies was used as a way to compare exposure levels between eastern and western North America as well as examine any differences between subspecies. Note that the eastern subspecies occurs generally in part of the American midwest, the Great Lakes region and southward towards Texas, while the western subspecies includes 
central and the western United States and western Mexico (Fig. 1).

Range location was included to examine if differences in $\mathrm{Hg}$ exposure occurred in different geographic areas on a smaller scale than subspecies. The range classes were chosen to reflect the broad geographic assignments from isotopes while maintaining adequate sample sizes for each category for statistical analyses. Range location included six categories based on subspecies and general position within the breeding range. The western north range included samples from British Columbia, and $\delta^{2} \mathrm{H}_{\mathrm{f}}$ values $\leq-80 \%$ o for the western subspecies (Appendix 1). The western central range location included samples from California, Oregon, and $\delta^{2} \mathrm{H}_{\mathrm{f}}$ values from $-50>-80 \%$ o for the western subspecies. The western southern range location included $\delta^{2} \mathrm{H}_{\mathrm{f}}$ values $-10>-50 \%$ or the western subspecies. The eastern north range included $\delta^{2} \mathrm{H}_{\mathrm{f}}$ values $\leq-50 \%$ o for the eastern subspecies. The eastern central range included $\delta^{2} \mathrm{H}_{\mathrm{f}}$ values $-40>-50 \%$ for the eastern subspecies. The eastern southern range included $\delta^{2} \mathrm{H}_{\mathrm{f}}$ values $-20>-40 \%$ for the eastern subspecies.

An interaction between subspecies and age was included to account for the potential difference in preformative moult between subspecies as described earlier. All factors were fixed factors because we were specifically interested in examining the effects of each factor level of each predictor on $\mathrm{Hg}$ levels in feathers.

For corticosterone samples $(n=196)$, models were conducted in the same way as for Hg. Minor differences for the age category for corticosterone samples was that the first cycle category contained one western chat in juvenal plumage and one western chat moulting into its formative plumage. Two chats in unknown plumage were lumped into the definitive cycle age category. Age, sex, subspecies, range location, and the interaction between age and subspecies were included as model parameters. We tested twelve exploratory models with different combinations of these predictors (Table 3 ).

Linear models were created using the lme4 package (v.1.1.21; Bates et al. 2015) in R. We inspected plots of the model residuals versus fitted values for the full model and for the top models to verify that the assumptions of linear models were met. The fit of each model was compared using the MuMIn package (v1.43.15; Barton 2019). We report $\triangle$ AIC values and relative weights for each model (Burnham and Anderson 2002). Conditional plots of the top model were implemented using the visreg package (v2.6.0; Breheny and Burchett 2017). If the top model had a weight of less than 0.90 , suggesting model uncertainty, then parameter estimates were calculated using a model averaging approach (Burnham and Anderson 2002). We computed the average model parameter estimates and $95 \%$ confidence intervals by factoring in the relative weight of the models
Table 2 Models compared to predict mercury in Yellow-breasted Chat (Icteria virens) feathers

\begin{tabular}{lccccc}
\hline Model & $\mathrm{K}$ & $\begin{array}{l}\text { Log- } \\
\text { Likelihood }\end{array}$ & AICc & $\Delta \mathrm{AIC}_{\mathrm{c}}$ & Weight \\
\hline $\begin{array}{l}\text { Age + Range } \\
\text { position }\end{array}$ & 8 & -137.00 & 291.03 & 0.000 & 0.754 \\
$\begin{array}{l}\text { Age + Sex + Range } \\
\text { Position }\end{array}$ & 10 & -136.45 & 294.49 & 3.458 & 0.134 \\
Age + Subspecies & 4 & -144.14 & 296.55 & 5.518 & 0.048 \\
Subspecies $\times$ Age & 5 & -143.60 & 297.61 & 6.584 & 0.028 \\
Age & 3 & -145.91 & 297.98 & 6.953 & 0.023 \\
Age + Sex + & 6 & -143.91 & 300.40 & 9.372 & 0.007 \\
Subspecies & & & & & \\
Sex + Age & 5 & -145.69 & 301.80 & 10.773 & 0.003 \\
Intercept-only model & 2 & -150.27 & 304.62 & 13.587 & 0.001 \\
Range position & 7 & -145.11 & 305.00 & 13.970 & 0.001 \\
Subspecies & 3 & -149.57 & 305.31 & 14.284 & 0.001 \\
Sex & 4 & -149.95 & 308.18 & 17.154 & 0.000 \\
Sex + Range & 9 & -144.47 & 308.23 & 17.199 & 0.000 \\
position & & & & & \\
Sex + Subspecies & 5 & -149.24 & 308.90 & 17.874 & 0.000 \\
\hline Kisthentmer of par & & & & & \\
\hline
\end{tabular}

$\mathrm{K}$ is the number of parameters. $\mathrm{AIC}_{\mathrm{c}}$ is Akaike's Information Criterion adjusted small sample sites. The total sample size is 150 . The response variable, mercury $(\mu \mathrm{g} / \mathrm{g})$ in Yellow-breasted Chat feathers, was $\log _{\mathrm{e}}$ transformed to improve model fit

Table 3 Comparing models to explain corticosterone in Yellowbreasted Chat (Icteria virens) feathers

\begin{tabular}{lcllll}
\hline Model & $\mathrm{K}$ & $\begin{array}{l}\text { Log- } \\
\text { Likelihood }\end{array}$ & $\mathrm{AIC}_{\mathrm{c}}$ & $\Delta \mathrm{AIC}_{\mathrm{c}}$ & Weight \\
\hline Subspecies & 3 & 115.69 & -225.26 & 0.000 & 0.455 \\
Age + Subspecies & 4 & 116.95 & -223.58 & 1.672 & 0.197 \\
Age $\times$ Subspecies & 5 & 115.84 & -223.48 & 1.782 & 0.187 \\
Sex + Subspecies & 5 & 116.02 & -221.72 & 3.539 & 0.078 \\
Age + Sex + & 6 & 116.19 & -219.94 & 5.320 & 0.032 \\
Subspecies & & & & & \\
Range position & 7 & 117.26 & -219.92 & 5.335 & 0.032 \\
Age + Range & 8 & 117.41 & -218.05 & 7.208 & 0.012 \\
position & & & & & \\
Sex + Range & 9 & 117.61 & -216.26 & 8.995 & 0.005 \\
position & & & & & \\
Age + Sex + & 10 & 117.77 & -214.34 & 10.91 & 0.002 \\
Range position & & & & & \\
Intercept- & 2 & 104.48 & -204.9 & 20.36 & 0.000 \\
only model & & & & & \\
Age & 3 & 105.10 & -204.08 & 21.18 & 0.000 \\
Sex & 4 & 105.49 & -202.77 & 22.49 & 0.000 \\
Sex + Age & 5 & 105.85 & -201.38 & 23.88 & 0.000 \\
\hline Kis the number & & & & & \\
\hline
\end{tabular}

$\mathrm{K}$ is the number of parameters. $\mathrm{AIC}_{\mathrm{c}}$ is Akaike's Information Criterion adjusted small sample sites. The total sample size is 196. Note that the response variable is corticosterone $(\mathrm{pg} / \mathrm{mm})$ in Yellow-breasted Chat feathers was transformed to the power of -0.7 to improve model fit 
using the model.avg function in MuMln. Parameter estimates shown are from the subset method, where only those models containing the parameters are used in estimation (Barton 2019). We also estimated parameters using the full method, where all models are used in estimation, and the results were similar and, therefore, are not reported. While our statistical approach used transformed values of corticosterone and $\mathrm{Hg}$ as indicated to meet model assumptions, we also present original values for visualization.

To examine whether there was a relationship between $\mathrm{Hg}$ and corticosterone ( $n=127$ birds where both were sampled), we ran a correlation analysis using the mosaic package (v.1.5.0; Pruim et al. 2017) in R for all birds, plus separately for birds in different age classes. To meet the assumption of bivariate normality, $\mathrm{Hg}$ values were $\log _{\mathrm{e}}$ transformed and corticosterone values were inversely transformed before analyses. Shapiro-Wilk's tests were conducted on the transformed variables to confirm normality.

\section{Results}

Stable hydrogen isotope values spanned between $-17.85 \%$ o and -90.38\%o (Appendix 1). The most depleted bins represent samples originating from the northern part of the chat's breeding range, and the least depleted bins represent samples originating from the southern part of their breeding range (Appendix 1).

\section{$\mathrm{Hg}$}

The average $\mathrm{Hg}$ levels in feathers across all chats were $0.30 \pm 0.02 \mu \mathrm{g} / \mathrm{g} \mathrm{dw}$. All samples were greater than the method limit of detection. The conversion of our feather $\mathrm{Hg}$ values to equivalent blood values using the equation from Jackson et al. 2011 resulted in 139 out of 150 (92.7\%) samples with negative values which were nonsensical. All values from Eagles-Smith et al. (2008) were above 0 . Regardless, the two transfer functions converting feather $\mathrm{Hg}$ to the equivalent blood levels resulted in the same number of chats falling within each $\mathrm{Hg}$ risk category. Almost all (98.6\%) chats had blood equivalent $\mathrm{Hg}$ levels considered background $(<0.2 \mu \mathrm{g} / \mathrm{g}$ ww blood equivalent). Only two chats $(1.3 \%)$ were in the low $\mathrm{Hg}$ toxicity risk category of $0.2-1 \mu \mathrm{g} / \mathrm{g}$ (ww blood equivalent), one of which originated from the Oregon I study area, and the other in the southwestern region $\left(\delta^{2} \mathrm{H}_{\mathrm{f}}:-30<-40 \%\right.$, Appendix 1$)$. No samples fell within the moderate, high, or severe risk categories for blood equivalent $\mathrm{Hg}$ toxicity.

Our isotopic assignments from overwintering sites combined with known breeding sites provided wide coverage of the chat breeding range (Fig. 2, Appendix 1).
However, geographic assignments from stable hydrogen isotopes are broad geographic areas and therefore, we cannot say with high precision where exact breeding occurred or $\mathrm{Hg}$ exposure. The two breeding sites with chats having the highest average $\mathrm{Hg}$ concentrations occurred in the southwest (Fig. 2). The sample size varied widely between breeding sites, with several sites represented by only 1 sample and so average values representing an entire area should be interpreted with caution.

$\mathrm{Hg}$ levels in chat feathers were best explained by a top model that included age and range position as predictors (Table 4, Online Resource 2). This model explained little variance in $\mathrm{Hg}$ levels in chats as the adjusted $\mathrm{R}^{2}$ value for this model was 0.13 . The weight of the top model was $75.4 \%$ suggesting that there is some uncertainty about model selection, therefore, all models were factored in for parameter estimation. $\mathrm{Hg}$ levels were lowest for chats in their definitive moult cycle (parameter estimate: $-0.44 \pm 12$ relative to first cycle moult; $95 \% \mathrm{CI}-0.67$ to -0.21 , Table 4, Fig. 3). Hg levels were lowest in the eastern subspecies' northern (parameter estimate: $-0.43 \pm 0.22 ; 95 \% \mathrm{CI}-0.86$ - -0.01) and central range locations (parameter estimate: $-0.46 \pm 0.19 ; 95 \%$ CI -0.82 to -0.09 , Table 4 , Fig. 3 ). No statistical differences were found between sexes or subspecies as these parameter estimates included 0 (Table 4 , Fig. 3).

Table 4 Weighted parameter estimates for mercury concentrations in Yellow-breasted Chats (Icteria virens) based on all models using the subset method

\begin{tabular}{|c|c|c|c|c|}
\hline & Estimate & Std. error & CI lower & CI upper \\
\hline$(\text { Intercept })^{\mathbf{a}}$ & -1.21 & 0.16 & -1.52 & -0.91 \\
\hline Age_-definitive cycle & -0.44 & 0.12 & -0.67 & -0.21 \\
\hline $\begin{array}{l}\text { Range position-West } \\
\text { Central }\end{array}$ & -0.03 & 0.17 & -0.35 & 0.30 \\
\hline $\begin{array}{l}\text { Range position- } \\
\text { West South }\end{array}$ & 0.11 & 0.21 & -0.30 & 0.53 \\
\hline $\begin{array}{l}\text { Range position-East } \\
\text { North }\end{array}$ & -0.43 & 0.22 & -0.86 & -0.01 \\
\hline $\begin{array}{l}\text { Range position-East } \\
\text { Central }\end{array}$ & -0.46 & 0.19 & -0.82 & -0.09 \\
\hline $\begin{array}{l}\text { Range position- } \\
\text { East South }\end{array}$ & 0.11 & 0.18 & -0.24 & 0.45 \\
\hline Sex-male & 0.10 & 0.13 & -0.14 & 0.35 \\
\hline Sex-unknown & 0.16 & 0.18 & -0.20 & 0.51 \\
\hline Subspecies-Eastern & -0.20 & 0.12 & -0.41 & 0.01 \\
\hline $\begin{array}{l}\text { Subspecies Eastern } \times \\
\text { Age-definitive }\end{array}$ & 0.23 & 0.23 & -0.22 & 0.68 \\
\hline
\end{tabular}

The $95 \%$ confidence intervals that do not include 0 are in bold

${ }^{a}$ The default values for categorical parameters are: Age $=$ first cycle, Subspecies $=$ western, Sex $=$ female, Range position $=$ Western North. All parameter estimates are relative to the intercept 


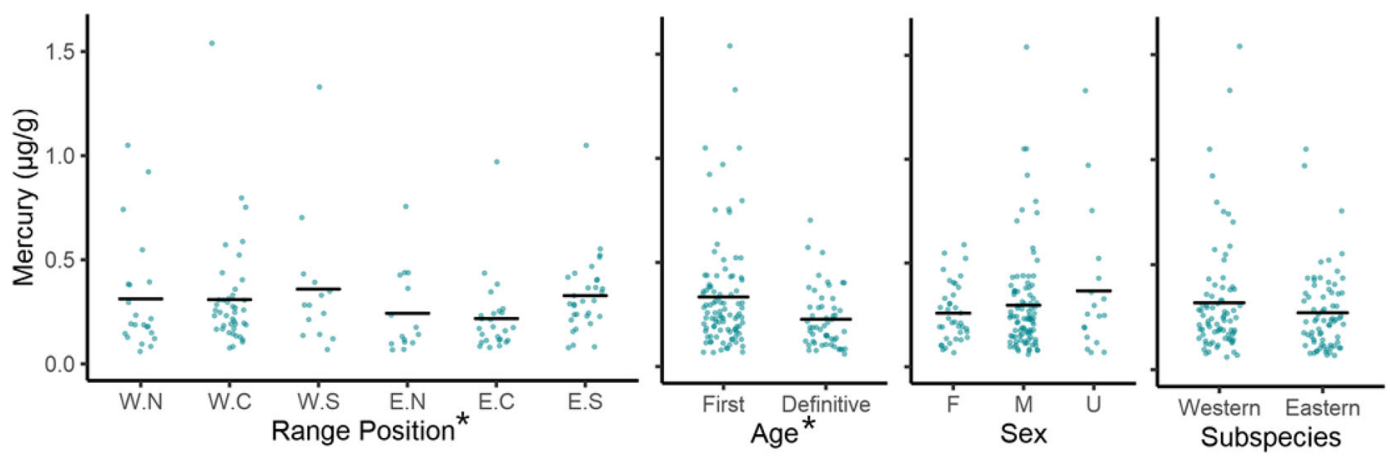

Fig. 3 Mercury concentrations in Yellow-breasted Chat (Icteria virens) feathers. Untransformed data and means are shown. The right outer tail feather was used. Range position is divided by subspecies (Western, W and Eastern E) and position within range (North, N; Central, C; and Southern, S). Sample sizes are W.N $=22$, W.C $=42$, W.S $=14$, E.N $=15, \mathrm{E} . \mathrm{C}=26, \mathrm{E} . \mathrm{S}=31$. Age includes the first moult cycle $(n=97)$ and the definitive moult cycle $(n=53)$. Sexes are female $(\mathrm{F}, n=38)$, male $(\mathrm{M}, n=94)$, and unknown $(\mathrm{U}, n=18)$. The total sample size is 150 . Parameters identified the top model are denoted with asterisks

\section{Corticosterone}

Corticosterone concentrations in feathers were on average $3.68 \pm 0.23 \mathrm{pg} / \mathrm{mm}$. One sample was slightly outside the range of the standard curve (i.e. $>20,000 \mathrm{pg} / \mathrm{ml}$ maximum) and therefore, the corticosterone concentration could not be calculated with confidence. Field notes show this bird had an unusual dark grey skin tone and may have had an underlying health issue; we omitted this sample, and our final sample size was 196. The inter-assay coefficient of variation was $11.3 \%$ and the intra-assay coefficient of variation was $3.2 \%$. No samples fell below the level of sensitivity.

The top model for corticosterone included subspecies as a predictor with a weight of $46.8 \%$ (Table 3, Online Resource 2). The adjusted $\mathrm{R}^{2}$ value of 0.091 indicates this model explained very little of the variance in feather corticosterone. Two other models were within $2 \Delta \mathrm{AIC}_{\mathrm{c}}$ units of the top model and included age + subspecies, and the interaction between age and subspecies as predictors and had model weights of $19.8 \%$ and $18.7 \%$, respectively (Table 3). Regardless, the low weight of the top model indicates there is some degree of model uncertainty, and therefore, we factored in all models for parameter estimates. Corticosterone levels were lowest for the eastern subspecies (parameter estimate: $-0.09 \pm 0.02$ relative to the wastern subspecies; 95\% CI: $-0.14--0.05$ ) and accordingly, all range positions for the eastern subspecies (Table 5, Fig. 4). Despite age being a parameter in the $2^{\text {nd }}$ and $3^{\text {rd }}$ top models, differences in corticosterone levels between the different age classes of chats were not statistically meaningful as the $95 \%$ confidence interval estimates included 0 . No differences were detected in corticosterone levels between sexes (Fig. 4).
Table 5 Weighted parameter estimates for corticosterone concentrations in Yellow-breasted Chats (Icteria virens) based on all models using the subset method

\begin{tabular}{|c|c|c|c|c|}
\hline & Estimate & Std. error & CI lower & CI upper \\
\hline$(\text { Intercept })^{\mathbf{a}}$ & -0.41 & 0.02 & -0.45 & -0.37 \\
\hline Subspecies-Eastern & -0.09 & 0.02 & -0.14 & -0.05 \\
\hline Age-definitive & 0.00 & 0.03 & -0.06 & 0.07 \\
\hline $\begin{array}{l}\text { Subspecies-Eastern } \times \\
\text { Age-Definitive }\end{array}$ & -0.07 & 0.05 & -0.16 & 0.02 \\
\hline Sex-male & 0.01 & 0.02 & -0.04 & 0.05 \\
\hline Sex-unknown & -0.03 & 0.04 & -0.11 & 0.05 \\
\hline $\begin{array}{l}\text { Range position-West } \\
\text { Central }\end{array}$ & -0.02 & 0.04 & -0.10 & 0.05 \\
\hline $\begin{array}{l}\text { Range position - } \\
\text { West South }\end{array}$ & 0.05 & 0.05 & -0.04 & 0.15 \\
\hline $\begin{array}{l}\text { Range position-East } \\
\text { North }\end{array}$ & -0.09 & 0.04 & $-\mathbf{0 . 1 8}$ & -0.02 \\
\hline $\begin{array}{l}\text { Range position-East } \\
\text { Central }\end{array}$ & -0.09 & $\mathbf{0 . 0 3}$ & -0.17 & -0.03 \\
\hline $\begin{array}{l}\text { Range position-East } \\
\text { South }\end{array}$ & -0.11 & 0.04 & -0.18 & -0.04 \\
\hline
\end{tabular}

The $95 \%$ confidence intervals that do not include 0 are in bold

${ }^{\mathrm{a}}$ The default values for categorical parameters are: Age $=$ first cycle, Subspecies $=$ western, Sex $=$ female, Range $=$ West North. All parameter estimates are reported relative to the intercept

\section{$\mathrm{Hg}$ and corticosterone combined}

We had 127 feather samples where both $\mathrm{Hg}$ and corticosterone were measured on the same individual. There was no correlation between $\mathrm{Hg}$ and corticosterone in chat feather samples (Fig. 5, $\mathrm{r}=-0.054$, df $=125,95 \%$ CI: -0.223 , 0.121 , P-value $=0.54)$. When the correlation analysis was repeated separately for birds in different age classes, still no 


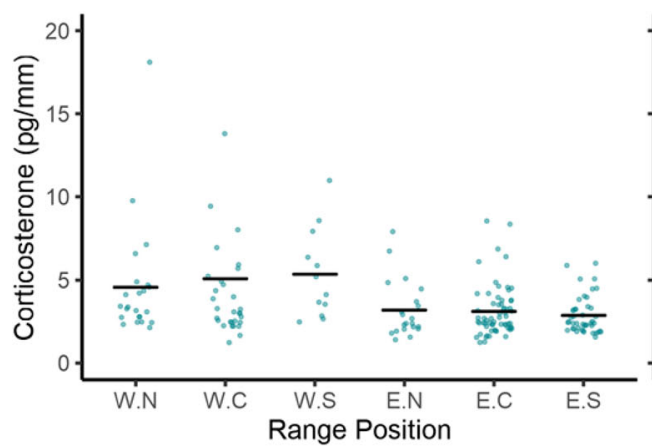

Fig. 4 Corticosterone concentrations in Yellow-breasted Chat (Icteria virens) feathers. Untransformed data and means are shown. The right outer tail feather was used. Range position is divided by subspecies (Western, W and Eastern E) and position within range (North, N; Central, C; and Southern, S). Sample sizes are W.N =23, W.C. $=31$,

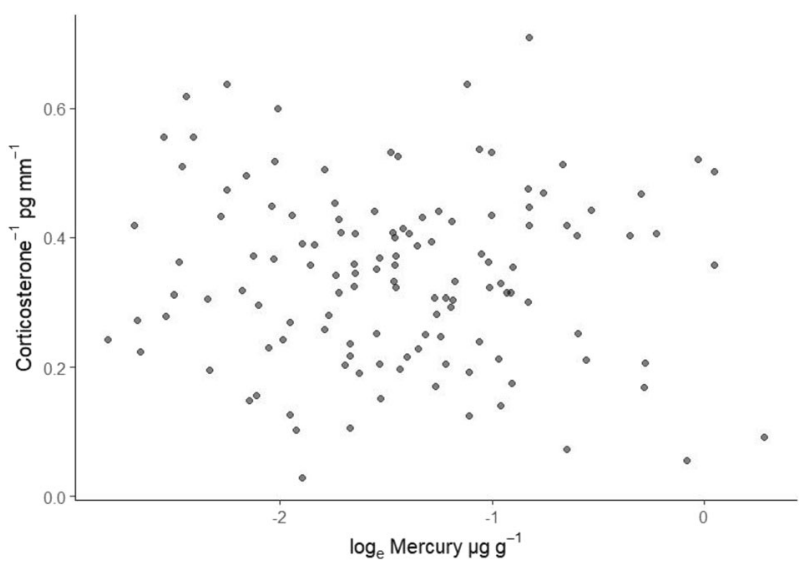

Fig. 5 Correlation between mercury and corticosterone in Yellowbreasted Chat (Icteria virens) feathers. Feathers represent breeding sites throughout North America $(N=127)$. Both variables were transformed to meet assumptions of normality. Pearson $\mathrm{r}=-0.054$, $\mathrm{df}$ $=125, p=0.54$

correlation was detected (first cycle birds: $\mathrm{r}=-0.103, \mathrm{df}=$ 82, 95\% CI: $-0.310,0.114$, P-value $=0.35$; definitive cycle birds: $\mathrm{r}=-0.037$, df $=41,95 \%$ CI: $-0.333,0.267$, $P$-value $=0.82$ ).

\section{Discussion}

We examined $\mathrm{Hg}$ concentrations in chats across their breeding range and found no evidence that this species is at risk of $\mathrm{Hg}$ toxicity despite their affinity for riparian habitats. Across all sites, $\mathrm{Hg}$ concentrations in chat feathers were within the range of equivalent blood $\mathrm{Hg}$ levels considered to be background, except for 2 out of 150 which were low risk of $\mathrm{Hg}$ toxicity (Ackerman et al. 2016). Age and range position were predictors for $\mathrm{Hg}$ in chats on a range-wide scale. $\mathrm{Hg}$ levels were greater in younger birds in their first moult cycle compared to older birds in their definitive moult

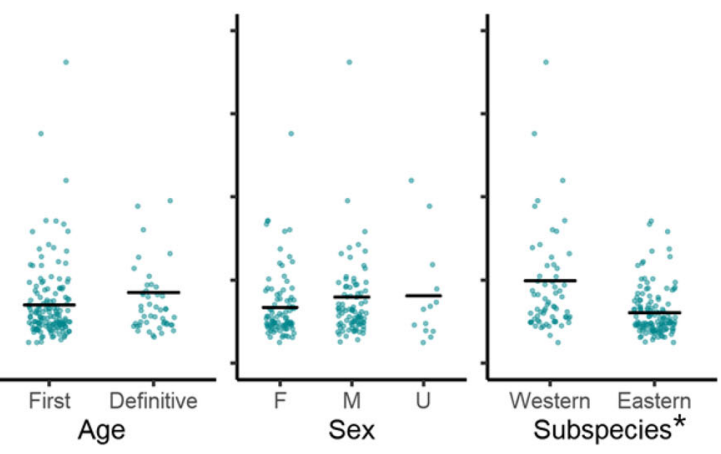

W.S. $=12$, E.N. $=21$, E.C $=64$, E.S. $=45$. Age includes the first moult cycle $(n=148)$ and the definitive moult cycle $(n=48)$. The total sample size is 196. Note that one outlier with corticosterone concentration of $35.53 \mathrm{pg} / \mathrm{mm}$ is not visible. The parameter identified in the top model is denoted with an asterisk

cycle. Hg levels were lowest in eastern chats that had bred in the north and central portion of their range. Subspecies was an important predictor for corticosterone in chats on range-wide scale. Corticosterone levels were greater in eastern chats than western chats. $\mathrm{Hg}$ and corticosterone levels were not correlated, suggesting no evidence of $\mathrm{Hg}$ affecting the normal function of the hypothalamus-pituitaryadrenal axis.

\section{Hg toxicity risk}

$\mathrm{Hg}$ levels in chat feathers were relatively low, $0.30 \pm$ $0.02 \mu \mathrm{g} / \mathrm{g} \mathrm{dw}$. The average level of $\mathrm{Hg}$ in tail feathers for chats in our study is slightly lower than the $0.4-0.7 \mu \mathrm{g} / \mathrm{g}$ $\mathrm{dw}$ averages reported for other songbirds in terrestrial habitats without a known point source of contamination (Óvári et al. 2018; Ma et al. 2018; Stenhouse et al. 2020). The two chats that fell within the low-risk category for blood equivalent levels $(0.2-1.0 \mu \mathrm{g} / \mathrm{g} \mathrm{ww})$ were at the low end of this range with equivalent blood $\mathrm{Hg}$ levels of less than $0.3 \mu \mathrm{g} / \mathrm{g}$ ww. These two chats are at minimal risk because most published effects within this category occur at blood $\mathrm{Hg}$ levels of $0.3 \mu \mathrm{g} / \mathrm{g}$ ww or greater (Ackerman et al. 2016). The only indication of a harmful effect of $\mathrm{Hg}$ at that level was reported in Lesser Scaup (Aythya affinis) experiencing some degree of oxidative stress at blood levels equivalent to $0.2 \mu \mathrm{g} / \mathrm{g}$ ww (Custer et al. 2000; Ackerman et al. 2016). Likewise, all values we converted to blood equivents were lower than the reproductive effect thresholds in for small birds of 2.1-4.2 $\mu \mathrm{g} / \mathrm{g}$ ww summarized from a meta-analysis by Fuchsman et al. (2017), further suggesting that chats are at little to no risk of mercury toxicity effects. Additionally, Jackson et al. (2015) had two blood samples from chats in contaminated sites in the Appalachian forests with a mean of $0.099 \mu \mathrm{g} / \mathrm{g}$ ww suggesting that even in contaminated sites, $\mathrm{Hg}$ toxicity risk is low for chats. 
We found no evidence of chats being at risk of $\mathrm{Hg}$ toxicity, despite living in riparian habitats, where $\mathrm{Hg}$ exposure can be greater as a result of feeding on aquatic insects from contaminated sediments or through aquaticterrestrial food web chains involving predatory invertebrates (Brasso and Cristol 2008; Cristol et al. 2008). The association with riparian or wetland habitats alone does not necessarily always indicate high $\mathrm{Hg}$ risk (Brasso et al. 2020). Brasso et al. (2020) advised caution on the generalization that songbirds in wetland habitats are at greater risk of $\mathrm{Hg}$ bioaccumulation after conducting a literature review. While chats consume both invertebrates and plants, it is likely that most invertebrates were of low trophic status or not linked to aquatic food webs. One study found that less than $2 \%$ of the chat diet was aquatic insects (Yard et al. 2004).

\section{Range-wide $\mathrm{Hg}$ predictors}

Females had slightly lower levels of $\mathrm{Hg}$ than males, although not statistically so, and this likely is a function of adult females depurating a relatively small amount of $\mathrm{Hg}$ (compared to feathers) into eggs (Honda et al. 1986; Rumbold et al. 2001; Agusa et al. 2005). Dietary intake of $\mathrm{Hg}$ is likely similar between sexes and this is not unexpected as we have not observed any sex-based differences in foraging habits and no studies on diet have indicated any sex-based differences (McKibbin and Bishop 2008; Eckerle and Thompson 2020). Other studies on songbirds have also found no difference in $\mathrm{Hg}$ levels between sexes (Warner et al. 2012; Keller et al. 2014).

It was unexpected that younger chats (in their first moult cycle) had higher levels of $\mathrm{Hg}$ than older chats (in their definitive moult cycle). Because $\mathrm{Hg}$ accumulates in the body between moulting periods (Evers 2018; Albert et al. 2019), we expected older birds to have the highest levels of $\mathrm{Hg}$ but our results do not support this idea. This trend has been reported elsewhere for other songbirds (Keller et al. 2014; Ma et al. 2018). One purported explanation for this phenomenon is that nestling birds have high energetic demands, especially for protein-rich foods, and, therefore, may be consuming higher volumes of insects and spiders, compared to older birds who may be eating proportionally more plant-based foods (Warner et al. 2012; Ma et al. 2018). This is likely true for chats because nestling chats are fed predominantly adult and larval insects (Schadd and Ritchison 1998) and occasionally berries (McKibbin and Bishop 2008) while adult chats consume roughly equal proportions of invertebrates and fruit (Howell 1932; Eckerle and Thompson 2020).

While our geographic assignments from hydrogen stable isotopes preclude precise estimates chat breeding location, the highest levels in our study generally occurred in western chats that had bred in the southwest. Hg hotspots have been identified in this area (Ackerman et al. 2016). Hg levels across the United States between 2013-2017 were highest in the central and western regions (National Atmospheric Deposition Program 2020). Hotspots of Hg exist in Nevada and California due to the gold rush and $\mathrm{Hg}$ mining (Commission for Environmental Cooperation 1997; Rytuba 2000; Alpers et al. 2005) and elevated $\mathrm{Hg}$ levels have been observed in birds in these regions (Henny et al. 2002; Hothem et al. 2008). Likewise, agricultural wetlands in the Central Valley of California, notably for rice production, use hydrological regimes that further promote $\mathrm{MeHg}$ production, more so than in naturally occurring wetlands (Windham-Myers et al. 2014). As Hg levels for adult chats in our study represent levels accumulated across the full annual cycle, western chats were likely exposed to these areas during migration and during breeding for some populations (Mancuso 2020). Chats may have also been exposed to higher levels of $\mathrm{Hg}$ during the non-breeding season in Mexico or Central America, as has been documented for the Bicknell's Thrush (Rimmer et al. 2005) from past and ongoing use of $\mathrm{Hg}$ in gold mining in the region (Canham et al. 2021). Additional studies at different parts of the annual cycle (e.g. using blood samples) would further elucidate where exposure is greatest as in our current study we cannot pinpoint where exposure occurred. Levels of $\mathrm{Hg}$ in chats were lowest in the eastern chat range, which was unexpected given that point sources of emissions for anthropogenic sources of $\mathrm{Hg}$ are greater in the eastern United States compared to the western United States (Eagles-Smith et al. 2016; AMAP/UN Environment 2019; Steenhuisen and Wilson 2019). It is also possible that $\mathrm{Hg}$ levels varied due to geographic differences in diet or trophic level (Keller et al. 2014; Ackerman et al. 2019; Li et al. 2021), but this would also require more in-depth study. Regardless, overall $\mathrm{Hg}$ levels in chats in our study were of low concern for toxicity, despite small-scale differences in $\mathrm{Hg}$ levels in breeding birds in various locations across their range.

We acknowledge that there have been mixed recommendations on using feathers, especially flight feathers, to draw conclusions about $\mathrm{Hg}$ exposure in birds (Bond and Diamond 2008; Peterson et al. 2019; Low et al. 2020). Hg levels in feathers generally correspond with the order of moult, with the first-moulted feathers containing the highest Hg levels (Furness et al. 1986; Bottini et al. 2021; Gatt et al. 2021). Most passerines replace their tail feathers about halfway through their moult beginning with the innermost tail feathers (Pyle 1997). Therefore, using tail feathers likely underestimates the true body burden of chat $\mathrm{Hg}$ concentrations accumulated since the last moult, but these are common feathers used in analyses and therefore are suitable for comparison (Warner et al. 2012; Pacyna et al. 2017; 
Óvári et al. 2018). We believe that the strength of our study is that the same methods were employed across all individuals in their range, allowing for suitable relative comparisons of $\mathrm{Hg}$ exposure between individuals and populations (Bortolotti 2010).

\section{Range-wide corticosterone predictors}

We found no differences in corticosterone levels in Yellowbreasted Chats of different ages or sexes but we did find differences between the eastern and western subspecies. Causes for these differences require further study, but possibilities include differences in life history and behaviour, which were suspected for differences in corticosterone for subspecies of Swamp Sparrows (Melospiza georgiana, Angelier et al. 2011). While statistically we found a difference in corticosterone levels between subspecies, the magnitude of the differences between the eastern and western are slight and therefore are unlikely to be meaningful in a biologically relevant context. Further investigation such as body condition or reproductive success would help to better contextualize potential differences between subspecies in relation to conservation physiology (Rich and Romero 2005; Dickens and Romero 2013; Boves et al. 2016).

The difficulty in predicting corticosterone is demonstrated by the top model having a very low $\mathrm{R}^{2}$ value, explaining very little of the variation in corticosterone in chats. Since the chats in our study were free-living wild birds, a multitude of other factors may influence corticosterone concentrations that we could not control, such as inclement weather (Wingfield et al. 1983; Ouyang et al. 2012), the presence of predators (Romero and Wingfield 2015), food abundance (Busch and Hayward 2009), injury (Sapolsky et al. 2000), human disturbance (Strasser and Heath 2013), immune status (Busch and Hayward 2009), and habitat quality (Marra and Holberton 1998), all of which vary in time and space. Quantifying such factors would be virtually impossible over such a large geographic area.

There is controversy on the usefulness of this hormone for conservation physiology, in particular, as an indication of stress in an organism (Romero 2004; Dickens and Romero 2013; Harris et al. 2017; MacDougall-Shackleton et al. 2019). As the main function of glucocorticoids relates to energy mobilization, levels of these hormones are not synonymous with stress (Busch and Hayward 2009; MacDougall-Shackleton et al. 2019). Additionally, levels of corticosterone vary drastically from species to species, and therefore, direct comparison of chats to other songbirds is not meaningful (Romero 2004), and therefore we did not compare our values to other species. Measures of body condition are often useful as a covariate in studies examining stress, as a decrease in mass has been the only consistent finding associated with chronic stress (Rich and Romero 2005; Dickens and Romero 2013). In our study, incorporating body condition was not possible because relevant body condition would have needed to be assessed the year prior during moult when corticosterone was incorporated into the feathers we collected. Regardless, our study provides range-wide baseline data on the functioning of the hypothamalus-pituitary-adrenal axis on the natal and breeding grounds for this species.

\section{Relationship between $\mathrm{Hg}$ and corticosterone}

We did not find any evidence of a correlative relationship between $\mathrm{Hg}$ and corticosterone in chats. Studies on Turkey Vultures (Cathartes aura) and Zebra Finches have also failed to find an increase in corticosterone with increasing Hg levels (Moore et al. 2014; Maddux et al. 2015; Herring et al. 2018). In contrast, a negative correlative relationship between corticosterone and $\mathrm{Hg}$ was detected in Forster's Terns (Sterna forsteri, Herring et al. 2012) and Tree Swallows (Franceschini et al. 2009), where high Hg levels correlated with low baseline corticosterone levels. The true association between these chemicals is unclear as results are inconsistent between studies (Whitney and Cristol 2017b) and may also be related to additional environmental contaminants, such as lead (Herring et al. 2018).

We acknowledge that a limitation in our study of using feathers to compare corticosterone and $\mathrm{Hg}$ is the different time frames these two signatures represent. $\mathrm{Hg}$ in feathers is accumulated since the last moult (up to a year for birds in their definitive moult cycle), while corticosterone is an integrated level over the period of feather growth ( weeks). Despite the mismatch in the timeframe for adult birds, $\mathrm{Hg}$ accumulates in the body and is highest at the time of moult (Albert et al. 2019), and as such we would expect the potential negative effects of $\mathrm{Hg}$ on the hypothalamuspituitary-adrenal axis and subsequent release of corticosterone to be most prominent during that time. The utility of correlations for physiological measures has also been disputed (Bortolotti 2010) but may be important starting points for future investigations when significant trends are detected. The geographic scale at which we compare corticosterone and $\mathrm{Hg}$ in the same individuals is unprecedented and allows for a broader understanding of these two biochemicals across various populations.

\section{Conclusions}

In conclusion, our study was the first range-wide study to examine both $\mathrm{Hg}$ and corticosterone in a free-living terrestrial songbird. While it is generally thought that 
organisms associated with wetland or riparian habitat are at higher risk of $\mathrm{Hg}$ exposure, we found that in the absence of a point source of contamination, chats are at low risk of $\mathrm{Hg}$ toxicity across their breeding range. Additionally, we found no evidence of $\mathrm{Hg}$ disrupting the normal function of the hypothalamus-pituitary-adrenal axis. Given that several populations of chats are of conservation concern, our results are reassuring that $\mathrm{Hg}$ and corticosterone are unlikely to be factors impeding their recovery.

\section{Data availability}

The datasets supporting the conclusions of this article will be available in the Open Science Framework repository.

Acknowledgements We would like to acknowledge all the skilled biologists, technicians, and volunteers who contributed to capturing chats and collecting feather samples, including but not limited to Matthias Bieber, Macgregor Aubertin-Young, Michael Bezener, Kristina Hick, Kiirsti Owen, Ingrid Tello-Lopez, Said Felix, Martín Aguilar, and Sarah Rockwell. Thank you to Jared Maida for training Kristen Mancuso on how to use the corticosterone ELISA kits. Many thanks to the En'owkin Centre and the Penticton Indian Band for their collaborative efforts with this research. Thank you to Emily Porter for their lab work with the National Wildlife Research Centre for processing the mercury samples. Thank you to Jason Pither and Adam Ford for reviewing the manuscript before submission for peer review. We also thank two anonymous reviewers whose suggestions were incorporated to improve the manuscript.

Author contributions $\mathrm{CAB}$ formulated the project idea. Funding for the project was secured by CAB, JDA, KM, and KEH. Field data were collected primarily by MG and KM plus additional samples from JDA and $\mathrm{CAB}$. Lab work quantifying corticosterone completed by KM. Mercury analyses were facilitated by JEE and conducted by MZ. KM performed all data analyses, created figures and tables, and wrote the manuscript. $\mathrm{KEH}, \mathrm{CAB}$, JDA, and JEE provided editorial advice.

Funding Funding for the project was provided by Environment and Climate Change Canada, NSERC, the University of British Columbia Okanagan, and Klamath Bird Observatory.

\section{Compliance with ethical standards}

Conflict of interest The authors declare no competing interests.

Ethical approval All research on birds was approved by the University of British Columbia Okanagan Animal Care Committee (application number A16-0079). Federal bird banding permits (10761L,10761Q, 10761R, 23206) were acquired for all bird banding activities.

Publisher's note Springer Nature remains neutral with regard to jurisdictional claims in published maps and institutional affiliations.

Open Access This article is licensed under a Creative Commons Attribution 4.0 International License, which permits use, sharing, adaptation, distribution and reproduction in any medium or format, as long as you give appropriate credit to the original author(s) and the source, provide a link to the Creative Commons license, and indicate if changes were made. The images or other third party material in this article are included in the article's Creative Commons license, unless indicated otherwise in a credit line to the material. If material is not included in the article's Creative Commons license and your intended use is not permitted by statutory regulation or exceeds the permitted use, you will need to obtain permission directly from the copyright holder. To view a copy of this license, visit http://creativecommons. org/licenses/by/4.0/.

\section{References}

Ackerman JT, Eagles-Smith CA, Herzog MP et al. (2016) Avian mercury exposure and toxicological risk across western North America: a synthesis. Sci Total Environ 568:749-769. https://doi. org/10.1016/j.scitotenv.2016.03.071

Ackerman JT, Hartman CA, Herzog MP (2019) Mercury contamination in resident and migrant songbirds and potential effects on body condition. Environ Pollut 246:797-810. https://doi.org/10. 1016/j.envpol.2018.11.060

Agusa T, Matsumoto T, Ikemoto T et al. (2005) Body distribution of trace elements in black-tailed gulls from Rishiri Island, Japan: age-dependent accumulation and transfer to feathers and eggs. Environ Toxicol Chem 24:2107-2120. https://doi.org/10.1897/ 04-617R.1

Albert C, Renedo M, Bustamante P, Fort J (2019) Using blood and feathers to investigate large-scale $\mathrm{Hg}$ contamination in Arctic seabirds: a review. Environ Res 177:108588. https://doi.org/10. 1016/j.envres.2019.108588

Alexander JD (2011) Advancing landbird conservation on western federally managed lands with management-and policy-relevant science. Dissertation, Prescott College, Prescott, Arizona, USA

Alexander JD, Ralph CJ, Hollinger K, Hogoboom B (2004) Using a wide - scale landbird monitoring network to determine landbird distribution and productivity in the Klamath-Siskiyou Region. In: Mergenthaler KL, Willians JE, Jules J (eds) Proceedings of the Second Conference on Klamath-Siskiyou Ecology. Siskiyou Field Institute, Cave Junction, Oregon, pp. 33-41

Alpers CN, Hunerlach MP, May JT, Hothem RL (2005) Mercury contamination from historical gold mining in California. Publ US Geol Surv 61:7

AMAP/UN Environment (2019) Technical background report to the global mercury assessment 2018. Arctic Monitoring and Assessment Programme. Oslo, Norway/UN Environment Programme, Chemicals and Health Branch, Geneva, Switzerland

Angelier F, Ballentine B, Holberton R et al. (2011) What drives variation in the corticosterone stress response between subspecies? A common garden experiment of swamp sparrows (Melospiza georgiana). J Evol Biol 24:1274-1283. https://doi.org/10.1111/j. 1420-9101.2011.02260.x

Barton K (2019) MuMIn: multi-model inference. R package version 1.43.15. https://cran.r-project.org/package $=$ MuMIn

Bates D, Mächler M, Bolker B, Walker S (2015) Fitting linear mixedeffects models using lme4. J Stat Softw 67:1-51. https://doi.org/ 10.18637/jss.v067.i01

Bond AL, Diamond AW (2009) Total and methyl mercury concentrations in seabird feathers and eggs. Arch Environ Contam Toxicol 56:286-291. https://doi.org/10.1007/s00244-008-9185-7

Bond AL, Diamond AW (2008) High within-individual variation in total mercury concentration in seabird feathers. Environ Toxicol Chem 27:2375-2377. https://doi.org/10.1897/08-163.1

Bortolotti GR (2010) Flaws and pitfalls in the chemical analysis of feathers: bad news-good news for avian chemoecology and toxicology. Ecol Appl 20:1766-1774. https://doi.org/10.1890/091473.1

Bortolotti GR, Marchant TA, Blas J, German T (2008) Corticosterone in feathers is a long-term, integrated measure of avian stress 
physiology. Funct Ecol 22:494-500. https://doi.org/10.1111/j. 1365-2435.2008.01387.x

Bottini CLJ, MacDougall-Shackleton SA, Branfireun BA, Hobson KA (2021) Feathers accurately reflect blood mercury at time of feather growth in a songbird. Sci Total Environ 775. https://doi. org/10.1016/j.scitotenv.2021.145739

Boves TJ, Fairhurst GD, Rushing CS, Buehler DA (2016) Feather corticosterone levels are related to age and future body condition, but not to subsequent fitness, in a declining migratory songbird. Conserv Physiol 4:1-12. https://doi.org/10.1093/conphys/cow041

Brasso R, Rittenhouse KA, Winder VL (2020) Do songbirds in wetlands show higher mercury bioaccumulation relative to conspecifics in non-wetland habitats? Ecotoxicology 29:1183-1194. https://doi.org/10.1007/s10646-020-02160-0

Brasso RL, Cristol DA (2008) Effects of mercury exposure on the reproductive success of tree swallows (Tachycineta bicolor). Ecotoxicology 17:133-141. https://doi.org/10.1007/s10646-0070163-z

Braune BM, Gaskin DE (1987) Mercury levels in Bonaparte's gulls (Larus philadelphia) during autumn molt in the Quoddy region, New Brunswick, Canada. Arch Environ Contam Toxicol 16:539-549. https://doi.org/10.1007/BF01055810

Breheny P, Burchett W (2017) Visualization of regression models using visreg. R J 9:56-71. https://doi.org/10.32614/RJ-2017-046

Burnham KP, Anderson DR (2002) Model selection and multimodel inference: a practical information-theoretic approach, 2nd edn. Springer-Verlag, New York, NY

Busch DS, Hayward LS (2009) Stress in a conservation context: a discussion of glucocorticoid actions and how levels change with conservation-relevant variables. Biol Conserv 142:2844-2853. https://doi.org/10.1016/j.biocon.2009.08.013

Canham R, González-Prieto AM, Elliott JE (2021) Mercury exposure and toxicological consequences in fish and fish-eating wildlife from anthropogenic activity in Latin America. Integr Environ Assess Manag 17:13-26. https://doi.org/10.1002/ieam.4313

Chin SY, Hopkins WA, Cristol DA (2017) Mercury alters initiation and construction of nests by zebra finches, but not incubation or provisioning behaviors. Ecotoxicology 26:1271-1283. https:// doi.org/10.1007/s10646-017-1852-x

Commission for Environmental Cooperation (1997) Ecological regions of North America: toward a common perspective. Commission for Environmental Cooperation, Montreal, Quebec

Courtiol A, Rousset F, Rohwader M-S et al. (2019) Isoscape computation and inference of spatial origins with mixed models using the $\mathrm{R}$ package IsoriX. In: Hobson KA, Wassenaar LI (eds) Tracking animal migration with stable isotopes, 2nd edn. Academic Press, London, UK, pp 207-237

Cristol DA, Brasso RL, Condon AM et al. (2008) The movement of aquatic mercury through terrestrial food webs. Science (80-) 320:335-335. https://doi.org/10.1126/science.1154082

Custer CM, Custer TW, Hill EF (2007) Mercury exposure and effects on cavity-nesting birds from the Carson River, Nevada. Arch Environ Contam Toxicol 52:129-136. https://doi.org/10.1007/ s00244-006-0103-6

Custer TW, Custer CM, Hines RK et al. (2000) Mixed-function oxygenases, oxidative stress, and chromosomal damage measured in lesser scaup wintering on the Indiana Harbor Canal. Arch Environ Contam Toxicol 38:522-529. https://doi.org/10.1007/ s002449910068

Dickens MJ, Romero LM (2013) A consensus endocrine profile for chronically stressed wild animals does not exist. Gen Comp Endocrinol 191:177-189. https://doi.org/10.1016/j.ygcen.2013. 06.014

Driscoll CT, Han Y, Chen CY et al. (2007) Mercury contamination in forest and freshwater ecosystems in the northeastern United States. Bioscience 57:17-28
Driscoll CT, Mason RP, Chan HM et al. (2013) Mercury as a global pollutant: sources, pathways, and effects. Environ Sci Technol 47:4967-4983. https://doi.org/10.1021/es305071v

Eagles-Smith CA, Ackerman JT, Adelsbach TL et al. (2008) Mercury correlations among six tissues for four waterbird species breeding in San Francisco Bay, California, USA. Environ Toxicol Chem 27:2136-2153. https://doi.org/10.1897/08-038.1

Eagles-Smith CA, Wiener JG, Eckley CS et al. (2016) Mercury in western North America: a synthesis of environmental contamination, fluxes, bioaccumulation, and risk to fish and wildlife. Sci Total Environ 568:1213-1226. https://doi.org/10.1016/j. scitotenv.2016.05.094

Eckerle KP, Thompson CF (2020) Yellow-breasted Chat (Icteria virens), version 1.0. Cornell Lab of Ornithology, Ithaca, NY

Edmonds ST, Evers DC, Cristol DA et al. (2010) Geographic and seasonal variation in mercury exposure of the declining rusty blackbird. Condor 112:789-799. https://doi.org/10.1525/cond.2010.100145

Environment and Climate Change Canada (2016) Recovery strategy for the Yellow-breasted Chat auricollis subspecies (Icteria virens auricollis) (Southern Mountain population) in Canada. Species at Risk Act Recovery Strategy Series. Environment and Climate Change Canada, Ottawa, ON

Environment and Climate Change Canada (2019) Recovery strategy for the Yellow-breasted Chat virens subspecies (Icteria virens virens) in Canada. Species at risk act recovery strategy series. Environment and Climate Change Canada, Ottawa, ON

Enzo Life Sciences Inc. (2018) Product manual - corticosterone ELISA kit. Catalogue No: ADI-900-097. Enzo Life Sciences Inc., Farmingdale, NY

ESRI (2019) ArcGIS Desktop 10.7.1. In: Redlands, CA Environ. Syst. Res. Inst. www.esri.com. Accessed 8 Nov 2020

Evers D (2018) The effects of methylmercury on wildlife: a comprehensive review and approach for interpretation. In: DellaSala DA, Goldstein MI (eds) Encyclopedia of the anthropocene. Elsevier Inc., Oxford, UK, pp 181-194

Evers DC, Burgess NM, Champoux L et al. (2005) Patterns and interpretation of mercury exposure in freshwater avian communities in northeastern North America. Ecotoxicology 14:193-221. https://doi.org/10.1007/s10646-004-6269-7

Evers DC, Jackson AK, Tear TH, Osborne CE (2012) Hidden risk: mercury in terrestrial ecosystems of the northeast. Report 2012-07. Biodiversity Research Institute, Gorham, Maine

Fairhurst GD, Damore N, Butler MW (2015) Feather corticosterone levels independent of developmental immune challenges predict carotenoid-based, but not melanin-based, traits at adulthood. Auk 132:863-877. https://doi.org/10.1642/AUK-15-34.1

Franceschini MD, Lane OP, Evers DC et al. (2009) The corticosterone stress response and mercury contamination in free-living tree swallows, Tachycineta bicolor. Ecotoxicology 18:514-521. https://doi.org/10.1007/s10646-009-0309-2

Fuchsman PC, Brown LE, Henning MH et al. (2017) Toxicity reference values for methylmercury effects on avian reproduction: critical review and analysis. Environ Toxicol Chem 36:294-319. https://doi.org/10.1002/etc.3606

Furness RW, Muirhead SJ, Woodburn M (1986) Using bird feathers to measure mercury in the environment: relationships between mercury content and moult. Mar Pollut Bull 17:27-30

Gahbauer MA, Smith C, Grosselet M, Ruiz GJ (2016) Influence of audio lures on capture rates of passerines during spring migration in Veracruz. Mexico. North Am Bird Bander 41:170-183

Gatt MC, Furtado R, Granadeiro JP et al. (2021) Untangling causes of variation in mercury concentration between flight feathers. Environ Pollut 269. https://doi.org/10.1016/j.envpol.2020. 116105

Grosselet M, Ruben J, Jaramillo N et al. (2014) Extensión de la muda preformativa del buscabreña (Icteria virens) a partir de individuos 
capturados durante la migración de otoño en el sur del estado de Veracruz, México. Huitzil 15:31-36

Harris CM, Madliger CL, Love OP (2017) An evaluation of feather corticosterone as a biomarker of fitness and an ecologically relevant stressor during breeding in the wild. Oecologia 183:987-996. https://doi.org/10.1007/s00442-017-3836-1

Harris CM, Madliger CL, Love OP (2016) Temporal overlap and repeatability of feather corticosterone levels: practical considerations for use as a biomarker. Conserv Physiol 4:1-11

Heddle C, Elliott JE, Brown TM et al. (2020) Continuous exposure to mercury during embryogenesis and chick development affects later survival and reproduction of zebra finch (Taeniopygia guttata). Ecotoxicology 29:1117-1127. https://doi.org/10.1007/ s10646-019-02074-6

Henny CJ, Hill EF, Hoffman DJ et al. (2002) Nineteenth century mercury: hazard to wading birds and cormorants of the Carson River, Nevada. Ecotoxicology 11:213-231. https://doi.org/10. 1023/A: 1016327602656

Herring G, Ackerman JT, Herzog MP (2012) Mercury exposure may suppress baseline corticosterone levels in juvenile birds. Environ Sci Technol 46:6339-6346. https://doi.org/10.1021/es300668c

Herring G, Eagles-Smith CA, Varland DE (2018) Mercury and lead exposure in avian scavengers from the Pacific Northwest suggest risks to California condors: implications for reintroduction and recovery. Environ Pollut 243:610-619. https://doi.org/10.1016/j. envpol.2018.09.005

Hobson KA, Wassenaar LI (2008) Tracking animal migration with stable isotopes. Academic Press, Burlington, MA

Hobson KA, Wassenaar LI (1997) Linking breeding and wintering grounds of neotropical migrant songbirds using stable hydrogen isotopic analysis of feathers. Oecologia 109:142-148

Honda K, Nasu T, Tatsukawa R (1986) Seasonal changes in mercury accumulation in the black-eared kite, Milvus migrans lineatus. Environ Pollution Ser A, Ecol Biol 42:325-334. https://doi.org/ 10.1016/0143-1471(86)90016-4

Hothem RL, Trejo BS, Bauer ML, Crayon JJ (2008) Cliff swallows Petrochelidon pyrrhonota as bioindicators of environmental mercury, Cache Creek Watershed, California. Arch Environ Contam Toxicol 55:111-121. https://doi.org/10.1007/s00244007-9082-5

Howell AH (1932) Florida bird life. Coward-McCann, New York

IAEA/WMO (2019) Global network of isotopes in precipitation. In: GNIP Database. http://www.iaea.org/water

IUCN (2016) Icteria virens. Data downloaded on December 12, 2016. www.iucnredlist.org

Jackson AK, Evers DC, Adams EM et al. (2015) Songbirds as sentinels of mercury in terrestrial habitats of eastern North America. Ecotoxicology 24:453-467. https://doi.org/10.1007/s10646-0141394-4

Jackson AK, Evers DC, Etterson MA et al. (2011) Mercury exposure affects the reproductive success of a free-living terrestrial songbird, the Carolina wren (Thryothorus ludovicianus). Auk 128:759-769

Jenni-Eiermann S, Helfenstein F, Vallat A et al. (2015) Corticosterone: effects on feather quality and deposition into feathers. Methods Ecol Evol 6:237-246. https://doi.org/10.1111/2041-210X.12314

Keller RH, Xie L, Buchwalter DB et al. (2014) Mercury bioaccumulation in Southern Appalachian birds, assessed through feather concentrations. Ecotoxicology 23:304-316. https://doi.org/10. 1007/s10646-013-1174-6

Kim EY, Murakami T, Saeki K, Tatsukawa R (1996) Mercury levels and its chemical form in tissues and organs of seabirds. Arch Environ Contam Toxicol 30:259-266. https://doi.org/10.1007/ BF00215806

Kleist NJ, Guralnick RP, Cruz A et al. (2018) Chronic anthropogenic noise disrupts glucocorticoid signaling and has multiple effects on fitness in an avian community. Proc Natl Acad Sci USA 115: E648-E657. https://doi.org/10.1073/pnas.1709200115

Lattin CR, Reed JM, Desrochers DW, Romero LM (2011) Elevated corticosterone in feathers correlates with corticosteroneinduced decreased feather quality: a validation study. J Avian Biol 42:247-252. https://doi.org/10.1111/j.1600-048X.2010. 05310.x

Li C, Xu Z, Luo K et al. (2021) Biomagnification and trophic transfer of total mercury and methylmercury in a sub-tropical montane forest food web, southwest China. Chemosphere 277:130371. https://doi.org/10.1016/j.chemosphere.2021.130371

Low KE, Ramsden DK, Jackson AK et al. (2020) Songbird feathers as indicators of mercury exposure: high variability and low predictive power suggest limitations. Ecotoxicology 29:1281-1292. https://doi.org/10.1007/s10646-019-02052-y

Ma Y, Branfireun BA, Hobson KA, Guglielmo CG (2018) Evidence of negative seasonal carry-over effects of breeding ground mercury exposure on survival of migratory songbirds. J Avian Biol 49:jav01656. https://doi.org/10.1111/jav.01656

MacDougall-Shackleton SA, Bonier F, Romero LM, Moore IT (2019) Glucocorticoids and "stress" are not synonymous. Integr Org Biol 1:1-8. https://doi.org/10.1093/iob/obz017

Maddux SL, Cristol DA, Varian-Ramos CW, Bradley EL (2015) The effect of mercury on baseline corticosterone in a breeding songbird. Bull Environ Contam Toxicol 94:135-139. https://doi.org/ 10.1007/s00128-014-1440-1

Mancuso KA (2020) Migration ecology of the Yellow-breasted Chat and Gray Catbird and physiology of the Yellow-breasted Chat. Dissertation, University of British Columbia Okanagan, Kelowna, British Columbia, Canada

Marra PP, Holberton RL (1998) Corticosterone levels as indicators of habitat quality: effects of habitat segregation in a migratory bird during the non-breeding season. Oecologia 116:284-292. https:// doi.org/10.1007/s004420050590

McKibbin R, Bishop CA (2010) Habitat characterization of breeding territories of the western Yellow-breasted Chat in the south Okanagan, British Columbia, Canada. Northwest Nat 91:145-156

McKibbin R, Bishop CA (2008) Feeding observations of the western Yellow-breasted Chat in the south Okanagan valley British Columbia, Canada during a seven-year study period. Br Columbia Birds 18:24-25

Monteiro LR, Furness RW (2001) Kinetics, dose-response, excretion, and toxicity of methylmercury in free-living Cory's shearwater chicks. Environ Toxicol Chem 20:1816-1823. https://doi.org/10. 1002/etc.5620200827

Moore CS, Cristol DA, Maddux SL et al. (2014) Lifelong exposure to methylmercury disrupts stress-induced corticosterone response in zebra finches (Taeniopygia guttata). Environ Toxicol Chem 33:1072-1076. https://doi.org/10.1002/etc.2521

National Atmospheric Deposition Program (2020) NADP Program Office, Wisconsin State Laboratory of Hygiene, 465 Henry Mall, Madison, WI 53706. http://nadp.slh.wisc.edu/MDN/annua lmdnmaps.aspx. Accessed 5 Apr 2020

New York State (2019) List of endangered, threatened, and special concern fish and wildlife species of New York State. Department of Environmental Conservation. https://www.dec.ny.gov/animals/ 7494.html. Accessed 1 Feb 2020

Ouyang JQ, Quetting M, Hau M (2012) Corticosterone and brood abandonment in a passerine bird. Anim Behav 84:261-268. https://doi.org/10.1016/j.anbehav.2012.05.006

Óvári M, Laczi M, Török J et al. (2018) Elemental composition in feathers of a migratory passerine for differentiation of sex, age, and molting areas. Environ Sci Pollut Res 25:2021-2034. https:// doi.org/10.1007/s11356-016-7787-6

Pacyna AD, Martínez CZ, Miguélez D et al. (2017) Mercury contamination, a potential threat to the globally endangered aquatic 
warbler Acrocephalus paludicola. Environ Sci Pollut Res 24:26478-26484. https://doi.org/10.1007/s11356-017-0201-1

Paris OJ, Swaddle JP, Cristol DA (2018) Exposure to dietary methylmercury solely during embryonic and juvenile development halves subsequent reproductive success in adult zebra finches. Environ Sci Technol 52:3117-3124. https://doi.org/10.1021/acs. est. $7 \mathrm{~b} 04752$

Peterson SH, Ackerman JT, Toney M, Herzog MP (2019) Mercury concentrations vary within and among individual bird feathers: a critical evaluation and guidelines for feather use in mercury monitoring programs. Environ Toxicol Chem 38:1164-1187. https://doi.org/10.1002/etc.4430

Pruim R, Kaplan, Daniel T, Horton, Nicholas J (2017) The mosaic package: helping students to think with data using R. R J 9:77. https://doi.org/10.32614/RJ-2017-024

Pyle P (1997) Identification guide to North American birds - part I. Slate Creek Press, Bolinas, CA

R Core Team (2018) R: a language and environment for statistical computing. R Found. Stat. Comput. Vienna, Austria. https://www.r-project.org/. Accessed 8 Nov 2020

Rich EL, Romero LM (2005) Exposure to chronic stress downregulates corticosterone responses to acute stressors. Am J Physiol Regul Integr Comp Physiol 288:1628-1636. https://doi.org/ 10.1152/ajpregu.00484.2004

Rimmer CC, Mcfarland KP, Evers DC et al. (2005) Mercury concentrations in Bicknell's thrush and other insectivorous passerines in montane forests of northeastern North America. Ecotoxicology $14: 223-240$

Ritz C, Baty F, Streibig JC, Gerhard D (2015) Dose-response analysis using R. PLoS ONE 10:e0146021. https://doi.org/10.1371/journa 1.pone. 0146021

Robinson SA, Lajeunesse MJ, Forbes MR (2012) Sex differences in mercury contamination of birds: testing multiple hypotheses with meta-analysis. Environ Sci Technol 46:7094-7101

Rockwell SM, Alexander JD, Stephens JL et al. (2017) Spatial variation in songbird demographic trends from a regional network of banding stations in the Pacific Northwest. Condor 119:732-744. https://doi.org/10.1650/CONDOR-17-44.1

Rockwell SM, Stephens JL (2018) Habitat selection of riparian birds at restoration sites along the Trinity River, California. Restor Ecol 26:767-777. https://doi.org/10.1111/rec.12624

Romero LM (2004) Physiological stress in ecology: lessons from biomedical research. Trends Ecol Evol 19:249-255. https://doi. org/10.1016/j.tree.2004.03.008

Romero LM, Wingfield JC (2015) Tempests, poxes, predators, and people: stress in wild animals and how they cope. Oxford University Press, New York, NY

Rumbold DG, Niemczyk SL, Fink LE et al. (2001) Mercury in eggs and feathers of great egrets (Ardea albus) from the Florida Everglades. Arch Environ Contam Toxicol 41:501-507. https:// doi.org/10.1007/s002440010277

Rytuba JJ (2000) Mercury mine drainage and processes that control its environmental impact. Sci Total Environ 260:57-71. https://doi. org/10.1016/S0048-9697(00)00541-6

Sapolsky RM, Romero LM, Munck AU (2000) How do glucocorticoids influence stress responses? Integrating permissive, suppressive, stimulatory, and preparative actions. Endocr Rev 21:55-89. https://doi.org/10.1210/er.21.1.55

Schadd CA, Ritchison G (1998) Provisioning of nestlings by male and female Yellow-breasted Chat. Wilson Bull 110:398-402

Scheuhammer AM (1987) The chronic toxicity of aluminum, cadmium, mercury, and lead in birds: a review. Environ Pollut 46:263-295

Scheuhammer AM, Meyer MW, Sandheinrich MB, Murray MW (2007) Effects of environmental methylmercury on the health of wild birds, mammals, and fish. Ambio 36:12-18
Seewagen CL (2010) Threats of environmental mercury to birds: knowledge gaps and priorities for future research. Bird Conserv Int 20:112-123. https://doi.org/10.1017/S095927090999030X

Seewagen CL (2020) The threat of global mercury pollution to bird migration: potential mechanisms and current evidence. Ecotoxicology 29:1254-1267. https://doi.org/10.1007/s10646-0181971-z

Shuford WD, Gardali T (2008) California bird species of special concern: a ranked assessment of species, subspecies, and distinct populations of birds of immediate conservation concern in California. Western Field Ornithologists, Camarillo, California, and California Department of Fish and Game, Sacramento, California

Siegel HS (1980) Physiological stress in birds. Bioscience 30:529-534

Soto DX, Koehler G, Wassenaar LI, Hobson KA (2017) Re-evaluation of the hydrogen stable isotopic composition of keratin calibration standards for wildlife and forensic science applications. Rapid Commun Mass Spectrom 31:1193-1203. https://doi.org/10.1002/ rcm.7893

Souza JS, Kasper D, da Cunha LST et al. (2020) Biological factors affecting total mercury and methylmercury levels in Antarctic penguins. Chemosphere 261. https://doi.org/10.1016/j. chemosphere.2020.127713

State of Connecticut (2015) Connecticut's endangered, threatened and special concern species. Department of Energy and Environmental Protection. Bureau of Natural Resources. https://www.ct. gov/deep/lib/deep/wildlife/pdf_files/nongame/ETS15.pdf. Accessed 1 Feb 2020

Steenhuisen F, Wilson SJ (2019) Development and application of an updated geospatial distribution model for gridding 2015 global mercury emissions. Atmos Environ 211:138-150. https://doi.org/ 10.1016/j.atmosenv.2019.05.003

Stenhouse IJ, Adams EM, Phillips LM et al. (2020) A preliminary assessment of mercury in the feathers of migratory songbirds breeding in the North American subarctic. Ecotoxicology 29:1221-1228. https://doi.org/10.1007/s10646-019-02105-2

Strasser EH, Heath JA (2013) Reproductive failure of a human-tolerant species, the American kestrel, is associated with stress and human disturbance. J Appl Ecol 50:912-919. https://doi.org/10.1111/ 1365-2664.12103

Tartu S, Angelier F, Wingfield JC et al. (2015a) Corticosterone, prolactin and egg neglect behavior in relation to mercury and legacy POPs in a long-lived Antarctic bird. Sci Total Environ 505:180-188. https://doi.org/10.1016/j.scitotenv.2014.10.008

Tartu S, Lendvai ÁZ, Blévin P et al. (2015b) Increased adrenal responsiveness and delayed hatching date in relation to polychlorinated biphenyl exposure in Arctic-breeding black-legged kittiwakes (Rissa tridactyla). Gen Comp Endocrinol 219:165-172. https://doi.org/10.1016/j.ygcen.2014.12.018

Thompson DR, Hamer KC, Furness RW (1991) Mercury accumulation in great skuas Catharacta skua of known age and sex, and its effects upon breeding and survival. J Appl Ecol 28:672-684

Wada H, Cristol DA, McNabb FMA, Hopkins WA (2009) Suppressed adrenocortical responses and thyroid hormone levels in birds near a mercury-contaminated river. Environ Sci Technol 43:6031-6038

Warner SE, Shriver WG, Olsen BJ et al. (2012) Mercury in wing and tail feathers of hatch-year and adult tidal marsh sparrows. Arch Environ Contam Toxicol 63:586-593. https://doi.org/10.1007/ s00244-012-9783-2

Whitney M, Cristol D (2017a) Rapid depuration of mercury in songbirds accelerated by feather molt. Environ Toxicol Chem 36:3120-3126. https://doi.org/10.1002/etc.3888

Whitney MC, Cristol DA (2017b) Impacts of sublethal mercury exposure on birds: a detailed review. In: de Voogt P (ed) Reviews of environmental contamination and toxicology. Springer International Publishing, Cham, Switzerland, pp. 113-163 
Windham-Myers L, Fleck JA, Ackerman JT et al. (2014) Mercury cycling in agricultural and managed wetlands: a synthesis of methylmercury production, hydrologic export, and bioaccumulation from an integrated field study. Sci Total Environ 484:221-231. https://doi.org/10.1016/j.scitotenv.2014.01.033

Wingfield JC (2013) Ecological processes and the ecology of stress: the impacts of abiotic environmental factors. Funct Ecol 27:37-44. https://doi.org/10.1111/1365-2435.12039

Wingfield JC, Moore MC, Farner DS (1983) Endocrine responses to inclement weather in naturally breeding populations of WhiteCrowned Sparrows (Zonotrichia leucophrys pugetensis). Auk 100:56-62
Wolfe JD, Ryder TB, Pyle P (2010) Using molt cycles to categorize the age of tropical birds: an integrative new system. J F Ornithol 81:186-194. https://doi.org/10.1111/j.1557-9263.2010.00276.x

Wolfe MF, Schwarzbach S, Sulaiman R (1998) Effects of mercury on wildlife: a comprehensive review. Environ Toxicol Chem 17:146-160

Yard HK, Van Riper III C, Brown BT, Kearsley MJ (2004) Diets of insectivorous birds along the Colorado River in Grand Canyon, Arizona. Condor 106:106-115

Yu MS, Eng ML, Williams TD et al. (2017) Assessment of neuroanatomical and behavioural effects of in ovo methylmercury exposure in zebra finches (Taeniopygia guttata). Neurotoxicology 59:33-39. https://doi.org/10.1016/j.neuro.2017.01.001 